\title{
JOINT OPERATING AGREEMENTS IN THE NEWSPAPER INDUSTRY: A THREAT TO FIRST AMENDMENT FREEDOMS
}

\section{ROBBIE STEEL $\dagger$}

To America, the newspaper business has always entailed far more than the selling of newspapers. Even publishers, whose ultimate focus is on the bottom line, recognize the magnitude of their responsibility to inform, educate, and entertain the public. Because publishers manifest their viewpoints not only on the editorial page but also through the scope, focus, and concentration of news coverage, ${ }^{1}$ the public benefits accruing from a free press are maximized by the existence of independent sources of news and opinion.

American courts traditionally have acknowledged that the marketplace of ideas realizes its greatest potential when the public is exposed to autonomous, competitive daily newspapers: "[the first amendment] rests on the assumption that the widest possible dissemination of information from diverse and antagonistic sources is essential to the welfare of the public ...."2 Desire to safeguard this interest ${ }^{3}$ and to halt the rapid decline of two-newspaper cities motivated Congress to enact the Newspaper Preservation Act of 1970 ("NPA"). ${ }^{4}$

The NPA adopted the premise that given the high costs of entry and competition, a competitive newspaper industry could not exist under the constraints of existing antitrust laws. ${ }^{5}$ Accordingly, the NPA sanctioned an exemption from those laws for joint newspaper

† B.S. 1987, J.D. Candidate 1990, University of Pennsylvania. Special thanks to Dan Segal for his assistance.

1 See B. Bagdikian, The Media Monopoly 16-17 (2d ed. 1987) (stating that while some publishers promote their self-interest by mandating or banning the editorial coverage of important news subjects, most publishers more subtly maintain control over news content through "the power to treat some subjects accurately but briefly, to treat other subjects accurately and in depth, ... [and by] carefully avoiding some subjects and enthusiastically pursuing others").

2 Associated Press v. United States, 326 U.S. 1, 20 (1945); see also Lively, Fear and the Media: A First Amendment Horror Show, 69 MINN. L. Rev. 1071, 1073 (1985) ("Content diversity in print is regarded, at least by the judiciary, as both essential to and a barometer of society's health.").

3 See 116 Cong. Rec. 2009 (1970) (statement of Sen. Moss) ("[T]he purpose of the act is to preserve editorial voices ....").

415 U.S.C. $\$ 1801$ (1982).

5 See 116 Cong. Rec. 23,148 (1970) (statement of Rep. McCulloch) ("It is the 
operating agreements ("JOAs"), which merge the operations and physical facilities of a "failing newspaper"6 with those of its competitor on the condition that the two newspapers maintain autonomous editorial and reportorial staffs. ${ }^{7}$ The Act grants participants in JOAs immunity from general antitrust laws and permits them to engage in such otherwise illicit practices as price-fixing, profit-pooling, and market allocation.

Proponents of the NPA envisioned JOAs as cost-effective substitutes for competitive newspapers that would ensure the continued existence of autonomous sources of news and opinion. However, the practical effect of JOAs has been to place a stranglehold on both the newspaper market and the marketplace of ideas. The financial advantages gained by newspapers engaging in JOAs deter new market entrants and inhibit smaller existing competitors while augmenting the substantial concentration of power in large newspaper chains.

Rather than preserving the existence of "diverse and antagonistic" voices, the Newspaper Preservation Act has merely preserved the status quo: the NPA has constrained, rather than furthered, first amendment interests. Newspapers operating under JOAs generally fail to provide greater depth of coverage or editorial diversity than monopolistic newspapers. The NPA is also impossible to implement: congressional enforcement of the conditions of editorial and reportorial autonomy necessarily entails government entry into the newsroom, thereby violating the first amendment.

The NPA's failure may be traced to a fundamental flaw in its underlying premise: the first amendment goal of providing varied sources of news and opinion is consistent with, rather than mutually exclusive of, the antitrust laws. ${ }^{8}$ The NPA accords the newspaper industry special, favorable economic treatment that inherently impedes true competitive journalism. The NPA's exemption of JOAs

potentially conflicting interest of commercial competition and editorial competition that we have pondered in our consideration of the Newspaper Preservation Act.").

6 The NPA defines a "failing newspaper" as "a newspaper publication which, regardless of its ownership or affiliations, is in probable danger of financial failure." 15 U.S.C. $\$ 1802(5)$ (1982). For further discussion of the implications of this definition, see infra notes 80-90 and accompanying text.

7 See 15 U.S.C. $\$ 1802(2)$ (1982).

8 See 116 Cong. REc. 2009 (1970) (statement of Sen. Hart) ("If the objective of the Congress is to preserve newspaper competition and encourage a multiplicity of editorial voices it should insist on strict enforcement of the antitrust laws and should not permit them to be weakened."). 
from the antitrust laws thus effectively thwarts the public interest in "diverse and antagonistic sources."

This Comment urges that the NPA's effectiveness be reexamined in light of the Act's consequences and effects. Part I outlines the background of the American newspaper industry. Part II explains the ways in which the NPA has failed to achieve its avowed goals of enhanced editorial diversity and improved quality of news coverage. Part III addresses the NPA's potential infringement of first amendment rights, both in conditioning the antitrust exemption on a content-based analysis of the newspapers' editorial and reportorial independence and in creating barriers to entry in the newspaper industry.

The need to reevaluate the NPA is particularly compelling in light of the Supreme Court's recent decision to hear Michigan Citizens for an Independent Press v. Thornburgh. ${ }^{9}$ The appellants in Michigan Citizens have challenged the Department of Justice's standard for granting JOAs as unduly permissive and have asserted that the antitrust exemptions allowed under the NPA serve as a catalyst provoking, rather than preventing, the collapse of independent competitive newspapers. Specifically, the appellants seek to halt the proposed JOA between the Detroit Free Press and The Detroit News on the grounds that neither newspaper is "failing" with sufficient certainty to warrant the drastic relief of a JOA. ${ }^{10}$ Although Michigan Citizens has been submitted and argued primarily on antitrust grounds, the Court should consider the critical threats to first amendment freedoms that are posed when JOAs are too readily sanctioned.

\section{BACKGROUND OF THE NEWSPAPER INDUSTRY}

The twentieth century has witnessed a dramatic decline in the number of cities served by more than one daily newspaper. In 1910, more than one-half of all "newspaper" cities enjoyed daily competition among as many as five or six newspapers; by 1986, however, newspaper monopolies had eliminated that competition in ninetyeight percent of these cities. ${ }^{11}$ This decline has been attributed primarily to economic developments unique to the newspaper industry.

9868 F.2d 1285 (D.C. Cir.), cert. granted, 109 S. Ct. 1952 (1989); see infra text accompanying notes $116-23$.

10 See supra note 6 and accompanying text; infra notes 80-90 and accompanying text.

II See B. Bagdikian, supra note 1, at 74. "Newspaper" cities are cities in which at least one daily newspaper is published. See id. 
The emergence and growth of broadcast media during the latter part of this century created new sources of rivalry for local advertising revenue; daily newspapers found themselves in competition not only with each other but also with television and a "resurgent" radio industry. ${ }^{12}$ The additional competition tightened a market already beset by financial constraints. ${ }^{13}$

Because newspapers operate on economies of scale, new entrants and smaller competitors have difficulty raising and maintaining sufficient capital. Similarly, larger established competitors must constantly battle against the "downward spiral" caused by the combined impact of declining circulation and diminishing advertising revenue.

The "downward spiral" effect reflects the unique relationship between circulation and advertising revenue that characterizes the newspaper industry. A newspaper can achieve an economy of scale only by increasing its circulation and can meet the costs of attaining such additional circulation only by attracting incremental advertising revenue. Thus, in a competitive market, a newspaper that gains an edge in circulation quickly secures a proportional advantage in revenue from advertisers seeking to reach the maximum number of readers. Because advertisers are generally less concerned with price than potential audience size, the weaker paper is precluded from effective competition. ${ }^{14}$ Furthermore, a circulation loss triggers both a proportionally greater loss of advertising revenue and a corresponding decline in news quality as funds that otherwise would have been allocated to news coverage instead are applied to offset the higher costs accompanying smaller circulation. The effect is a vicious "downward spiral" that is "rarely reversed." 15

Joint newspaper operating arrangements were initially developed to allow weaker newspapers to escape this cycle while preserving autonomous editorial voices. ${ }^{16}$ JOAs existed long before the

12 See Martel \& Haydel, Judicial Application of the Newspaper Preservation Act: Will Congressional Intent Be Relegated to the Back Pages?, 1984 B.Y.U. L. Rev. 123, 130; see also Note, Newspaper Preservation Act: A Critique, 46 IND. L.J. 392, 395 (1970) (stating that proponents of the NPA blame the decline in two-newspaper cities on increased competition from radio and television).

13 The effect of competition was particularly acute in urban neighborhoods, where blue-collar workers preferred the more "easily digested" material featured in broadcast news. See Martel \& Haydel, supra note 12, at 130.

14 For a more detailed explanation of the downward spiral effect, see Media and the First Amendment in a Free Society, 60 GEo. L.J. 867, 894 (1972) [hereinafter Media and the First Amendment ]; Note, supra note 12, at 395 \& n.21.

15 See Martel \& Haydel, supra note 12, at 130.

16 See supra notes 4-7 and accompanying text. 
enactment of the NPA in 1970. The first JOA was formed in Albuquerque, New Mexico, in 1933, and twenty-two JOAs had been implemented by the time of the Act's passage. ${ }^{17}$

The NPA was precipitated by allegations that JOAs violated national antitrust laws. In 1969, the Supreme Court addressed the legality of JOAs in Citizen Publishing Co. v. United States. ${ }^{18}$ The Citizen Publishing Court upheld a district court decision to invalidate the JOA between the Citizen and The Arizona Daily Star as violative of sections one and two of the Sherman Act ${ }^{19}$ and section eighteen of the Clayton Act. ${ }^{20}$ The Court specifically objected to the JOA's sanctioning of three types of controls-price fixing, profit pooling, and market control. ${ }^{21}$ The decision did not directly outlaw JOAs but rather required a revision of the Tucson JOA that would eliminate the offensive provisions. ${ }^{22}$

In ruling the violations "plain beyond peradventure," the Citizen Publishing Court noted that "[the only real defense of the] appellants was the 'failing company' defense-a judicially created doctrine."23 This doctrine permits an exemption to the antitrust laws when a company would face certain failure if no action were taken. The Court noted, however, that the failing company doctrine had traditionally been limited to instances in which the prospect of rehabilitation was so remote that the company "faced the grave probability of a business failure" and in which "no other prospective purchaser" existed. ${ }^{24}$ The Court consequently held that because there was no evidence that the owners of the weaker Citizen were even contemplating a sale or other alternative to the JOA, the failing company doctrine could not be invoked. ${ }^{25}$

17 See S. Oppenheim \& C. Shields, Newspapers and the ANTtTrust Laws 187 (1981).

18394 U.S. 131 (1969).

1915 U.S.C. $\S \S 1,2$ (1982).

2015 U.S.C. $\$ 18$ (1982).

21 See Citizen Publishing, 394 U.S. at 135-36. Price-fixing is "[t]he cooperative setting of price levels or ranges by competing firms." BLACK's LAw Dictionary 1070 (5th ed. 1979). Profit-pooling is the agreement between firms in a combination to share the profits obtained through that combination. See id. at 1045. Market control results from the agreement between those firms to concentrate on particular target areas so that the combination will dominate the entire market. See 3 P. Areeda \& D. TURNER, ANTTTRUST LAW $\$ 703$, at 111-14 (1978).

22 See Citizen Publishing, 394 U.S. at 135.

23 Id. at 135-36.

24 Id. at 137 (quoting International Shoe Co. v. FTC, 280 U.S. 291, 302 (1930)).

25 See id. (" $[T]$ here is no evidence that the joint operating agreement was the last straw at which the Citizen grasped."). 
Concern over the far-reaching implications of the Citizen Publishing decision induced powerful newspaper groups to lobby Congress for statutory support for JOAs, culminating in the Newspaper Preservation Act of 1970. The NPA permits JOAs to engage in the activities prohibited by Citizen Publishing on the condition that one newspaper qualify as "failing." 26 The standard of failure was defined far more broadly than in Citizen Publishing, requiring only that a newspaper, "regardless of its ownership or affiliations, is in probable danger of financial failure."27

\section{Failure of the NPA to Aghieve its Avowed Goals}

\section{A. Lack of Need for an Exemption Under the Antitrust Laws}

The less stringent standards sanctioned by the NPA ostensibly promote the first amendment interest in protecting the dissemination of "diverse and antagonistic" sources of information. ${ }^{28}$ While the importance of that concern is indisputable, no causal relationship has been established between the NPA and the achievement of that goal. Exemptions to the antitrust laws traditionally have been granted only upon a showing of urgency and dire need; ${ }^{29}$ in the case

26 See 15 U.S.C. $\$ 1803$ (1982). Although the NPA did not explicitly mention the practices outlawed by Citizen Publishing, it included an extremely broad definition of "joint newspaper operating arrangement" in 15 U.S.C. \$ 1802(2) (1982), which has been interpreted as establishing that "the main elements objected to in Citizen Publishing, the joint determination of advertising and subscription rates and the pooling of profits, are permissible in a [JOA] that meets the requirements of the [NPA]." S. OpPEnheim \& C. Shields, supra note 17, at 191; see also 116 Conc. ReC. 23,146 (1970) (statement of Rep. Kastenmeier) (admitting that most JOAs have provisions allowing price-fixing, profit-pooling, and market allocation).

2715 U.S.C. $\S 1802(5)$ (1982). The official reason for the less stringent standard was recognition of the unique difficulties the newspaper industry faced in combatting the downward spiral effect. See S. Oppenheim \& C. Shields, supra note 17, at 193. Critics of the NPA, however, have charged that the standard was influenced by the substantial power that large newspaper groups wielded over Congress and President Nixon. See infra text accompanying notes 68-80.

28 For a discussion of more political motives that may have provided the true impetus for the NPA's passage, see infra text accompanying notes 68-76.

29 The government will intervene in a "natural monopoly" market to simulate the more egalitarian economic conditions that characterize competitive markets. See L. Sullivan, ANTrtrust 717 (1977). In implementing the NPA, however, the government sanctioned monopolistic practices in an otherwise free market. See infra notes 173-74 and accompanying text for a discussion of why the economic conditions in the newspaper industry at the time of the NPA's passage did not constitute a "natural monopoly." Similar exemptions have been granted for small businesses, see 15 U.S.C. $\$ 640$ (1982), and companies engaged in activities directly affecting national defense, see 50 U.S.C. $\$ 2158$ (1982). The national defense exemption is sustained by the government's compelling interest in protecting its citizens. See $1 \mathrm{P}$. 
of the NPA, however, both the necessity of such an exemption and the effectiveness of antitrust exemptions in achieving editorial diversity are unsubstantiated. ${ }^{30}$

Despite the undisputed findings documenting the inherent difficulties in maintaining two-newspaper cities, the NPA's proponents failed to establish either that the demise of all independent newspaper competition was inevitable or that the JOA was the only or best means of circumventing this dilemma. Although one legislator cited testimony that most of the newspapers that collapsed did so primarily because of "failure of the paper to relate to the needs and wants of [a changing] community,"31 Congress largely ignored the impact of noneconomic factors such as mismanagement, poor or irrelevant article content, and the migration of large numbers of readers from the cities to the suburbs. ${ }^{32}$

AreedA \& D. Turner, supra note $21, \S 230 \mathrm{~b}$, at 224-25. The small business exemption is justified by its positive impact on the nation's economy and on the grounds that many combinations of small businesses "have so little market power as to be presumptively reasonable and therefore lawful under the Sherman Act \& 1." Id. $\S 230 c$, at 225.

The exemption most analogous to the NPA is the Webb-Pomerene Act, 15 U.S.C. $\$ \S 61-65$ (1982), which exempts from the antitrust laws agreements in the course of export trade between associations formed solely for the purpose of engaging in such trade. The Webb-Pomerene Act was deemed necessary to enable American firms to compete on an equal level in a trade world dominated by cartels. See 1 P. AREedA \& D. Turner, supra note $21, \S 230$ a, at 222 . Like the NPA, the WebbPomerene Act was supported by a powerful and influential lobby and involves matters highly vulnerable to political pressures. See Hawk, International Antitrust Policy and the 1982 Acts: The Continuing Need for Reassessment, 51 FordHaM L. REv. 201, 22729 (1982); see also infra notes 68-76 and accompanying text (discussing the political pressures influencing the NPA's passage). A successful challenge to the NPA could potentially limit the Attorney General's authority to allow mergers under the export trading exemption. See White \& Wermiel, High Court to Hear Antitrust Challenge To Merger of Detroit's Two Big Dailies, Wall St. J., May 2, 1989, at B5, col. 5.

30 "The antitrust laws embody concepts and principles which long have been considered to be the bedrock of our economic institutions. Piecemeal exemptions from the antitrust laws to cope with problems of particular industries have been given reluctantly and only after there has been a clear showing of overriding need." 116 Cong. Rec. 23,145 (1970) (statement of Rep. Kastenmeier) (quoting Rep. Celler); see also id. at 23,167 (statement of Rep. Edwards) ("[E]nactment of [the NPA] would be such a major exemption of the Federal antitrust laws as to make it unwise.").

31116 Cong. Rec. 2010 (1970) (statement of Sen. Hart) (quoting Ben Bagdikian, who was then national news editor of the Washington Post).

32 See Note, The Newspaper Preservation Act: The Seattle Application, 1982 U. ILL. L. REv. 669, 693. Congress also failed to acknowledge the possibility that technological developments in the printing industry could "ease the economies of scale problem and, in the long run, lead to a rebirth of competing daily newspapers." Shenefield, Ownership Concentration in Newspapers, 65 A.B.A. J. 1332, 1332 (1979). 
Particularly troubling was Congress' willingness to relieve owners and publishers of all responsibility for their predicaments. The assumption that a newspaper's demise could be halted only by a JOA obscured the fact that "costs ... can be cut and have been cut by many newspapers" both through labor-saving technology and production and through more streamlined, efficient management. ${ }^{33}$ In a letter urging rejection of the NPA, the National Newspaper Association noted the survival of competition among "independent, wholly separate" newspapers in thirty-seven American cities and asked "why the 'joint newspaper operators' benefitted by [the proposed NPA] cannot also survive without special legislation?"34

Congress' most glaring oversight, however, was its failure to acknowledge the economic flexibility remaining in the newspaper industry even after the ruling in Citizen Publishing. The Citizen Publishing Court merely affirmed the illegality of JOAs that engaged in price-fixing, profit-pooling, and market allocation-activities in direct violation of the Sherman and Clayton Acts. The decision did not prohibit the joinder of printing, distribution, or other business departments in compliance with existing antitrust laws. The Department of Justice indicated that the standards established in Citizen Publishing could be applied successfully to all JOAs in effect at the time of that decision. ${ }^{35}$

Even in the absence of monopolistic practices, the legal joinder of business departments may be sufficient to sustain an otherwise profitable newspaper: "The greatest economies result from merged printing and distribution facilities and the courts have found that this is not forbidden by the antitrust laws." 36 The potential savings under such an arrangement preclude the argument that JOAs are the necessary-and the only-means of preventing the demise of twonewspaper cities.

The "need" for an antitrust exemption is further obscured by the lack of positive proof establishing that the monopolistic practices permitted under the exemption are necessary to achieve successful JOAs. ${ }^{37}$ A prospectus filed by a joint agreement half-owner with the

33116 Cong. Rec. 23,163 (1970) (statement of Rep. Brown).

34 Id. at 23,144 (statement of Rep. MacGregor) (quoting letter from the National Newspaper Association (July 2, 1970)).

35 See id. at 23,150 (statement of Rep. MacGregor).

36 Id. at 23,175 (letter from Andrew J. Biemiller, Director of the Department of Legislation for the AFL-CIO, to Rep. Kastenmeier).

37 See 116 Cong. Rec. 23,156 (1970) (statement of Rep. Feighan) ("No evidence has been presented which demonstrates that price fixing and profit pooling are necessary to the successful joint operation of newspapers."); see also Mintz, What the 
Securities and Exchange Commission after the Citizen Publishing decision noted that requiring JOAs to conform to the standards established in Citizen Publishing could increase costs and decrease profits; the prospectus did not suggest that the decline in profitability would force one of the newspapers to close. ${ }^{38}$ Failure to establish that JOAs are essential to the preservation of independent newspapers substantially weakens the premise on which the NPA was founded and undermines the legitimacy of the Act. ${ }^{39}$

Furthermore, JOAs have not proved an infallible remedy. The first JOA approved after the NPA's passage took place between the Anchorage Daily News and the Anchorage Times in 1974; by 1978, that JOA had disintegrated into a $\$ 16.5$ million mismanagement lawsuit by the News against the Times. ${ }^{40}$ The two newspapers ultimately agreed to an out-of-court settlement in which the JOA was terminated, with the financially troubled News receiving $\$ 750,000$ and its independence from the Times. ${ }^{41}$ Since the demise of the Anchorage JOA, the weaker newspapers in the JOAs in Columbus, Miami, and St. Louis have each collapsed, thereby effectively severing those JOAs. ${ }^{42}$ "[E]xperts predict that another six or eight JOA papers may be killed within the next 15 years as agreements near expiration and

Vice President and the Press Kept Dark: Spiro Agnew's Candles, New Republic, Jan. 17, 1970 , at 13, 14 (noting "the lack of any indication that such extreme measures as price fixing or profit pooling are in fact necessary to permit the independent existence of today's newspapers," (quoting Richard McLaren, Assistant Attorney General for Antitrust)), reprinted in 116 Cong. REC. 2014-15 (1970).

38 See 116 Cong. REC. 2010 (1970) (statement of Sen. Hart).

39 See Note, supra note 12, at 399 (stating that since the proponents of the NPA did not demonstrate that a substantial number of newspapers would fail without the exemption, the congressional conclusion that the antitrust exemption present in the NPA is necessary for the preservation of competing and independent news sources is unwarranted).

40 See Anchorage Dailies to End Joint Agreement in April, Edror \& Publisher, Oct. 7, 1978 , at 7 .

41 See id. The News' dire economic straits were attributed partially to factors unique to the Alaska market. See, e.g., Hein, Preservation Law Fails to Help Anchorage News, Editor \& Publisher, Nov. 6, 1976, at 7 (discussing the possibility that the extremely cold Alaskan mornings make it more difficult for a morning newspaper, such as the News, to enjoy financial success). The failure of the Anchorage JOA nevertheless demonstrates that a JOA does not guarantee financial success.

42When the agreement for joint operations between the Columbus CilizenJournal and Columbus Dispatch expired in 1985, the Citizen-Journal was closed because the operation was unprofitable despite the act. Operation of the St. Louis Globe-Democrat became unprofitable despite its agreement with the Post-Dispatch and Newhouse Newspapers decided to close it. Another firm purchased the Globe-Democrat but it soon went into bankruptcy and the paper died in 1986. The Miami News ceased publication in December of last year after renegotiating its agreement with its JOA partner, the Herald. Under 
as the dominant JOA publishers decide that a one-newspaper monopoly is even more profitable than a two-newspaper monopoly."43

Proponents of the NPA too readily discarded alternative solutions and overlooked the potential for favorable results in agreements that did not contain antitrust exemptions. Although JOAs were hailed as less monopolistic than complete mergers of two newspapers under one owner, their advocates failed to realize that there is greater room for entry into a market dominated by the latter. ${ }^{44}$ Furthermore, no qualitative proof established that JOAs produce greater editorial diversity than newspapers published under common ownership. ${ }^{45}$ By allowing natural market forces to govern the newspaper industry, Congress would have maximized access to the daily newspaper market and more effectively accomplished its avowed goal of preserving "diverse and antagonistic" sources. ${ }^{46}$

\section{B. Failure To Enhance News and Editorial Coverage}

The NPA presumed that financially strong newspapers would be less concerned with pandering to the public and more willing to take "courageous and unpopular" positions on current issues. ${ }^{47}$ Both the quality and diversity of news and editorial coverage were expected to improve with passage of the Act. Results have failed to measure up

the new agreement, the News' owner, Cox Newspapers, will receive as much as $\$ 300$ million from Knight-Ridder for closing the paper.

Oversight Hearing on the Operations of the Newspaper Preservation Act Exemption from the Antitrust Laws Before the Subcomm. on Economic and Commercial Law of the House Comm. on the Judiciary, 101st Cong., 1st Sess. (1989) [hereinafter NPA Oversight Hearing] (statement of Robert G. Picard, Ph.D., at 2) (separately paginated by commentators' statements).

43 NPA Oversight Hearing, supra note 42 (statement of Bruce B. Brugmann, editor and publisher of the San Francisco Bay Guardian and president of the Association of Alternative Newsweeklies, at 2).

44 See infra note 177 and accompanying text.

45 See 116 Cong. Rec. 23,152 (1970) (statement of Rep. Dennis) (claiming that two newspapers published under common ownership may maintain "vigorous conflicting editorial policies," and indicating that "the joint newspaper operating agreement is not essential to the maintenance of a separate or an independent editorial voice").

46 University of California-Berkeley School of Law Professor Stephen R. Barnett argued, even before the enactment of the NPA, that the absence of JOAs would cause some newspapers to fail. Barnett reportedly claimed, however, that those papers then would be replaced by other newspapers, "nurturing a more robust, more truly independent, editorial climate." Doll, Antitrust Law Meets The Press, NaT'L L.J., Oct. 15, 1984, at 1, 26 (paraphrasing Barnett).

47 See Note, supra note 12 , at $406 \&$ n.76 (quoting S. REP. No. 535, 91 st Cong., lst Sess. 3-4 (1969)). 
to expectations, however, and no positive correlation has been established between JOAs and improved diversity or quality of editorial or news coverage. ${ }^{48}$

\section{Failure To Achieve Editorial Diversity}

Legislators first expressed doubts about the accuracy of the NPA's premise during the congressional debates. ${ }^{49}$ The bill's opponents claimed that cooperation did not enhance editorial quality or diversity but rather obstructed the achievement of those goals. ${ }^{50}$ The bill's proponents failed to counter these claims with definitive proof of benefits arising from JOAs. ${ }^{51}$ Studies undertaken since the NPA's enactment have verified the initial fears. One study concluded that papers joined under a JOA generally do not provide two discrete community voices, ${ }^{52}$ while another study found that "the content of these papers seems slightly more similar to the content in competitive papers than in noncompetitive ones."53

48 See Lively, New Media, Old Dogma, 30 ArIz. L. Rev. 257, 265 (1988) (claiming that "assumptions that first amendment values are promoted by cooperation rather than competition have not been proved to be entirely correct").

49 See, e.g., 116 Cong. Rec. 2008 (1970) (statement of Sen. Percy) ("I am not sure that the [NPA] ... will . . . strengthen an independent editorial voice that would otherwise be stilled.").

50 See, e.g., id. at 23,150 (statement of Rep. MacGregor) ("[T]he sheltered environment of a carefully divided market is a poor spur to editorial ingenuity and [sic] creativity." (quoting Preserving Press Diversity, N.Y. Times, Jan. 31, 1970, at 30, col. 2)); see also id. at 23,157 (statement of Rep. Mikva) ("Newspaper combinations involving such close community of economic interest as price-fixing and profit pooling have resulted largely in less diversity of news coverage and muted expressions of ideological differences ...." (quoting AFL-CIO Resolution on the Newspaper Antitrust Exemption)). During the debates, Representative Kastenmeier produced a letter from the AFL-CIO expressing that organization's doubts "that the exemption is without danger to independence of news coverage and ideological viewpoint, as the sponsors of the legislation contend." Id. at 23,175 (statement of Rep. Kastenmeier) (quoting letter from Andrew J. Biemiller, Director of Department of Legislation, AFL-CIO).

51 See id. at 2012 (statement of Sen. Perry) ("[N]o formal study was undertaken or presented to prove or disprove the contention that news and editorial operations in [JOAs] are in fact any better. for the public than they would be under one ownership ... . News and editorial matters are inextricably intertwined with economic matters, but the questioning of witnesses has been aimed only at the latter." (quoting Rowse, The 'Failing' Newspaper Probe: The Press Dummies Up, 208 NATION 816 (1969)).

52 See Ardoin, A Comparison of Newspapers Under Joint Printing Contracts, 50 JoURNALISM Q. 340, 347 (1973).

53 Id. at 345. But see H. Levin, Broadcast Regulation and Joint OWNership of MEDIA 83 \& n.20 (1960) (citing numerous studies indicating that "the actual contents of newspapers operating independently in the same community ... apparently show little difference in the handling of important social, political, and other problems"). 
The failure of JOAs to achieve true editorial diversity is largely attributable to inherent pragmatic difficulties. The very nature of a JOA necessitates a close business relationship between the member papers that can easily influence editorial and news content. ${ }^{54}$ Furthermore, both newspapers, in pooling their advertising rates, cater to the same market of prospective advertisers and are subject to the same management biases to avoid controversial topics that could potentially endanger these economically valuable relationships. ${ }^{55}$

Although little empirical evidence exists quantifying the effectiveness or ineffectiveness of JOAs, two examples illustrate the contrast in diversity between markets that enjoy free competition and markets dominated by JOAs. The potential for editorial collusion was demonstrated by the two papers operating under the San Francisco JOA: the Chronicle and the Examiner. The Examiner's coverage of the Chronicle's struggle to renew its broadcast license and of the FCC's decision to deny that license was "delayed and minimal," implying that editorial independence may be compromised on any issue in which either JOA member possesses a vested interest. ${ }^{56}$

Conversely, the increased quality generated by direct competition is evidenced in the struggle between the four independent daily New York newspapers:

[T] he ... clear winner is the New York newspaper-reading public. By importing its tradition of top-flight local and investigative reporting, New York Newsday has forced the other papers, including the Times, to compete on a higher level, and new columnists introduced by the three tabloids consistently turn out first-rate work. ${ }^{57}$

The criteria used in one study of JOAs are discussed infra text accompanying note 132.

54 See Note, supra note 32, at 691-92.

55 See Media and the First Amendment, supra note 14, at 897; cf. H. Levin, supra note 53 , at 84 (attributing the lack of significant difference in the content of two independent newspapers in the same city to "the fact that two publishers are both businessmen," which "may overshadow their differences as individuals").

56 See Note, supra note 12, at 410. The NPA's opponents also feared that JOAs would provide incentives for publishers to conspire to take turns advocating unpopular stances or to moderate opposing stances. See, e.g., 116 ConG. REc. 23,143 (1970) (statement of Rep. Thompson) ("If there is a so-called separate editorial policy, then one may well believe that the managers of the two newspapers get together and one decides, 'Well, now, which side are you going to take? Which side am I going to take? Let us not be too extreme on this. Let us kind of work together." ").

57 Zuckerman, The Last Siand of the Tabloids, Time, Mar. 13, 1989, at 81. 


\section{Failure To Improve Quality Of News Coverage}

In addition to compromising the independence of editorial coverage, the lack of direct competition between newspapers under JOAs stifles the caliber of news coverage. Robert Picard, head of a three-year Louisiana State University project focusing on press concentration, discerned a strong positive correlation between competition and quality of coverage. According to Picard, quality declines drastically under JOAs: "The journalism suffers. There are exceptions, but in general if there is no direct head-to-head competition, no incentives, it depends on the pride of the organization. If you don't have that pride, you get cutbacks in news services, cutbacks in locally produced copy, staff reductions."58 This analysis of JOAs contrasts sharply with the situation in New York, where steep competition has forced all three tabloids to improve the quality of their news coverage. ${ }^{59}$

\section{Effects of Unanticipated "Competition"}

At the time of the NPA's enactment, the newspaper industry did not face today's wealth of competition from radio and television. ${ }^{60}$ The NPA's proponents nonetheless erred in failing to view the newspaper industry in the context of the vast multi-media spectrum and in refusing to recognize the competition arising from "the plethora and cacophony of voices" that characterizes the national media. ${ }^{61}$ Derick Daniels, executive editor of the Detroit Free Press in 1970, noted the far-reaching impact of the broadcast media industry's growth: "In this decade, newspapers will not compete simply with each other - or simply with TV, or movies, or magazines. No, they will have to compete simultaneously with the whole multi-media extravaganza of light and sound and type and motion in a war for the individual's time." 62

58 Randolph \& Behr, Newspaper Preservation Law Produces Windfalls, Wash. Post, July 13, 1986, at All, col. 5 (quoting Picard). Opponents of the pending Detroit JOA have expressed similar concerns, fearing that "the lack of competition will sap some of the fire from the city's two big papers, leaving Detroit poorer." Id.

59 See supra note 57 and accompanying text.

60 See, e.g., Thomas, Pie in the Sky: Newspapers Sell at Record Highs on Main Street and Wall Street, BARrons, Nov. 17, 1969, at 3, 18 (stating that in 1969, "the newspaper has little advertising competition from the local airwaves"), reprinted in 116 CoNG. REc. 2011 (1970); see also supra text accompanying notes 12-13.

61 See Lively, supra note 48 , at 266 ("The NPA, in seeking to perpetuate an industry based upon dated imagery, disregards the broader media galaxy in which newspapers exist.").

62 Daniels, The World of Multi-Media: The Kingdom Is Run by Readers; Power Is Being 
The NPA has also proven unresponsive to internal developments within the newspaper industry, specifically the emergence of competition from national and suburban newspapers. ${ }^{63}$ The national desk of a city newspaper competes against not only its intracity rival but also the national desks of other major city newspapers and national newspapers such as USA Today and The Wall Street Journal. Similarly, "metropolitan" staffs of major city newspapers face competition in "breaking" local stories from suburban newspapers. ${ }^{64}$ These structural changes within the newspaper industry have been heralded as "improv[ing] the quality and extent of coverage" 65 and have generated the competition that the NPA sought to preserve.

The NPA's inflexibility has rendered it obsolete in an era characterized by the development of new media sources. This inflexibility has further inhibited first amendment freedoms by imposing artificial restraints upon the marketplace of ideas. ${ }^{66}$ In failing to anticipate the competition that would inevitably arise from technological advances, the NPA has imposed rigid and enduring confines that frustrate its avowed purpose.

\section{Undesired Results of the NPA}

\section{Increased Influence of Newspaper Chains}

Despite the lack of proof that the newspaper industry had established a compelling need for exemption from the antitrust laws, the NPA easily passed both the House and the Senate and received almost immediate presidential approval. ${ }^{67}$ The bill's breezy path

Believed; And Glory Comes After the Midnight Movie, Quill, July 1970, at 8, 11, cited in Loevinger, Media Concentration: Myth and Reality, ANTITRUST Bull. Fall 1979, at 479, 492 n.36.

63 See Lively, supra note 48, at 265-66.

64 An analogous situation exists in Florida, where the size and shape of the state stimulate fierce competition among newspapers in different cities because "nobody is very far away from somebody else." Henry, The Best Papers Under the Sun: In Florida, Competition Breeds Quality, Not Cheap Sensation, Time, Apr. 26, 1982, at 66 (quoting Orlando Sentinel Star Editor David Burgin). Between 1962 and 1982, Florida newspapers won more Pulitzer Prizes (eight) than did the newspapers of any other state; according to Miami Herald Executive Editor John McMullan, the incentive for quality is high because "[i]f you don't put out a good newspaper in Florida, somebody else will." Id.

65 Lively, supra note 48 , at 266.

66 Cf. id. at 267 ("Pursuit of first amendment goals by official enactments that do not factor in the possibility of or adapt readily to changed circumstances is itself a dangerous exercise.").

67 The NPA was passed by the Senate on January 30,1970 , by a vote of 64-13. 
through Congress suggests that its enactment was less attributable to its merits than to "some of the most intensive lobbying ever seen on Capitol Hill" by newspaper editors, publishers, and even reporters. ${ }^{68}$ Because of the American press' powerful influence over electoral politics, legislators seeking reelection were particularly vulnerable to the pressure of media lobbying groups. ${ }^{69}$ Congressmen who opposed the NPA warned against allowing self-interest to motivate the passage of otherwise unwarranted legislation. As one congressman noted: "In the absence of a compelling showing of the threat of failure, this House should be most skeptical of inferring that the danger of newspaper failure is the real motive behind this bill." 70

The lobbying efforts of the press extended beyond Congress to President Richard Nixon. In a letter to Nixon, Hearst Corporation president and chief executive officer Richard W. Berlin described the NPA as "a matter of common interest to both you and me."71 Berlin's implications were spelled out still more clearly in a letter to Richard W. McLaren, Nixon's assistant attorney general in charge of antitrust: "[T]here was almost unanimous support of the Administration by the newspapers who are proponents of the Newspaper Preservation Act. It therefore seems to me that those newspapers

See 116 Cong. Rec. 2017 (1970). The House vote, on July 8, 1970, was 292-87. See id. at 23,179 . The bill was signed into law on July 24,1970 . See 15 U.S.C. $\S 1801$ (1982).

68116 Cong. Rec. 2013 (1970) (statement of Sen. Hart) (quoting Rowse, supra note 51 , at 818 ).

69 See id. at 2012 (statement of Sen. Hart) ("The pressure that has pushed [the NPA] ahead of countless more important measures in the past few months is silent tribute to the power of the big publishers to get almost anything they want from publicity-hungry politicians." (quoting Rowse, supra note 51, at 816)).

The power of the forces lobbying for congressional support may be inferred from the nature of the NPA's staunchest supporters: the American Newspaper Publishers Association and the chains of Scripps-Howard, Hearst, Newhouse, Knight, Block, and Cox, each of which had at least one member paper involved in a JOA during the lobbying period for the NPA. See id.

70116 Cong. Rec. 23,157 (1970) (statement of Rep. Mikva); see also id. at 2009 (statement of Sen. Hart) ("[A]Il the [NPA] will preserve are the monopoly profits of a small group of publishers who have achieved those profits by price fixing, profit pooling, and market division."); id. at 23,149 (statement of Rep. MacGregor) ("If [preserving editorial diversity and competition in ideas] were the actual raison d'etre for the bill, no fault could be found with it. But this rationale is a thin facade which is not supported by the content of our hearings and which cannot stand searching analysis.").

71 B. Bagdikian, supra note 1, at 96 (quoting letter from Richard W. Berlin to President Richard M. Nixon (undated)). 
should, at the very least, receive a most friendly consideration."72 Several weeks later, the Nixon Administration reversed its earlier opposition to the bill, ${ }^{73}$ and President Nixon signed the NPA into law in July. ${ }^{74}$ In the 1972 election, despite his administration's wellknown attacks upon other first amendment rights, ${ }^{75}$ Nixon received the highest percentage of newspaper endorsements of any candidate in modern American history. ${ }^{76}$

Powerful pressure to enact the NPA was exerted by media chains such as Hearst. ${ }^{77}$ Significantly, the House report on the bill noted that fifteen of the twenty-two pre-existing JOAs involved members of national newspaper chains. ${ }^{78}$ The chains successfully wielded their influence over politicians through their substantial control over national editorial content ${ }^{79}$ and ensured that they would retain their concentration of industry power.

72 Id. at 97 (quoting letter from Richard W. Berlin to Richard W. McLuren (undated)).

73 See id. at 98.

74 See supra note 67. Ironically, from a survey of 20 newspapers with preexisting JOAs, only 13 carried stories mentioning the NPA's passage in the week after it passed the Senate. Only five of these newspapers listed the 22 cities affected, and only two, the Nashville Tennessean and the Salt Lake City Deseret News, admitted that they specifically benefitted from the legislation. See A. BALK \& J. BOYLAN, OUR Troubled PRESS 262 (1971).

75 See, e.g., B. BAgdikian, supra note 1, at 99 ("For four years the Nixon administration had attacked not only the news media but their constitutional rights. Nixon had sent his vice-president on a crusade attacking newspapers that criticized the White House or ran news of negative events that were normal fare in ordinary reportage. In the Pentagon Papers case the Nixon administration obtained the first court-ordered cessation of publication in the country's history.").

76 See id. Although Bagdikian's analysis suggests that Nixon's generous attitude towards the NPA was motivated by desire for favorable press treatment in the impending election, "[s]ome believe that Nixon saw the [NPA] not as a way to gain favor, but as his final revenge on the press. He couldn't control the media, so the Act would encourage his arch-enemies to devour themselves." NPA Oversight Hearing, supra note 42 (statement of W. Edward Wendover, Editor and Publisher, The Community Crier, Plymouth-Canton, Michigan, at 3).

77 See B. Bagdikian, supra note 1, at 95; see also 116 Cong. Rec. 2009 (1970) (statement of Sen. Hart) (noting that the characterization of the NPA as "a millionaire-crybabies-publishers" bill" was "not an inappropriate label").

78 See H.R. REP. No. 1193, 91 st Cong., 2d Sess. 5, reprinted in 1970 U.S. CodE Conc. \& Admin. News 3547, 3549-50.

79 Studies have established that chains exert significant political pressure over their subsidiaries' editorial content. See B. BAGDikian, supra note 1, at 84 . The Cox and Scripps-Howard chains require all of their papers to endorse the same national candidates, and Scripps-Howard annually adopts a uniform stand on major issues. See id. A Joumalism Quarterly study published in 1975 noted that "the vast majority of chains exhibited homogeneous endorsement patterns in the four presidential election years studied [1960, 1964, 1968, 1972]." Chain Newspaper Autonomy as Reflected in Presidential Campaign Endorsements, 52 JourNaLISM Q. 411,419 (1975). 
The chains' influence dictated the NPA's definition of "failing newspaper" as "a newspaper publication which, regardless of its ownership or affiliations, is in probable danger of financial failure." 80 This provision, which allows a chain to participate as the owner of either the stronger or the weaker paper, was intended as "an order to view the newspaper as ' $a$ free-standing entity, as if it were not owned by a corporate parent." "81 Because it allows chains to expand their already substantial power, this definition permits the preservation of JOAs at the expense, rather than the enhancement, of editorial diversity. ${ }^{82}$

The Act's requirement that JOAs be evaluated without respect to ownership further ignores the potential for chains to exploit their widespread power through predation. "Predatory cross-subsidization" allows a company to charge high prices in markets with comparatively low competition and to use those profits to subsidize lower prices in more competitive markets, thereby achieving monopoly or near-monopoly status in all markets. ${ }^{83}$ In the pending battle between the Detroit Free Press and The Detroit News, both Knight-Ridder and Gannett have been charged with financing their continued losses through the monopoly profits of other newspapers in the chains. ${ }^{84}$

The statutory definition also disregards the inherent advantages chain owners enjoy under the NPA. A publisher may foist a substantial amount of unnecessary or unwanted services on its subsidiaries

8015 U.S.C. $\S 1802(5)$ (1982) (emphasis added).

81 Michigan Citizens for an Indep. Press v. Attorney Gen., 695 F. Supp. 1216, 1220 (D.D.C. 1988) (quoting Committee for an Indep. P-I v. Hearst Corp., 704 F,2d 467, 480, cert. denied, 464 U.S. 892 (1983)), aff'd sub nom. Michigan Citizens for an Indep. Press v. Thornburgh, 868 F.2d 1285 (D.C. Cir.), cert. granted, 109 S. Ct. 1952 (1989). Later applications of the NPA have posited little doubt that " $[t]$ he legislative history and language ... [were] intended to permit chain-owned newspapers to apply for the Act's exemption." Note, supra note 32, at 678.

82 See Note, supra note 32, at 696. "Congress narrowed in on preserving editorial competition between forty-four joint operating newspapers while ignoring the larger problem of preserving or encouraging nationwide diversity." $I d$.

The expansive definition of failing newspapers encourages chains to conspire to force one newspaper within the statutory definition. When this occurs, both newspapers may engage in otherwise illegal monopolistic practices that completely bar new market entrants. See infra notes 91-106 and accompanying text; $c$. Glassman, Paper Chase; The Money Culture, New Republic, June 23, 1988, at 11 (alleging that Gannett's CEO, Alan Neuharth, used profits from smaller papers in the Gannett chain to finance the purchases of larger newspapers).

83 See Busterna, Newspaper JOAs and the Logic of Predation, Coмm. \& L., Apr. 1988, at $3,5 \&$ n.7.

84 See id. at 14 \& n.34. 
in order to facilitate those newspapers' abilities to show the "losses" necessary to qualify for a JOA. ${ }^{85}$ The NPA's failure to account for ownership permits chains to manipulate the statutory language to maintain their superior market positions; ${ }^{86}$ such a result contradicts the legislative intent that JOAs be established only as last resorts. ${ }^{87}$

The vague nature of the statutory definition also effectively thwarts the alleged impetus behind the NPA: the preservation of "diverse and antagonistic" sources. ${ }^{88}$ The chains' financial strength provides significant advantages in combatting the financial pressures of the newspaper industry, ensuring their continued domination of that field. Because most newspapers in a given chain generally endorse the same political candidate ${ }^{89}$ and are similarly unreceptive to minority viewpoints, the NPA effectively reduces the number of voices in the marketplace of ideas. ${ }^{90}$ In doing so, the NPA creates a result that directly contradicts its avowed goal.

85 See Note, supra note 32 , at 687 \& n.130. A more realistic evaluation is provided by a "net benefit analysis" of what the chain truly derives from the paper, encompassing such factors as tax benefits accruing from losses and the purchase of services from the parent company. See id. at 687.

86 The Antitrust Division based its rejection of the Hearst Corporation's application for a JOA in part on the grounds that the Hearst newspapers received a net financial benefit from the loss; however, the ALJ and the Attorney General refused to apply net benefit analysis claiming that it violated the statutory definition of "failure" under the NPA. See id. at 687-88.

Similarly, in the controversy over the Detroit JOA, the ALJ predicted that the Free Press would "not enter the downward spiral so long as Knight-Ridder remains in Detroit." Michigan Citizens for an Indep. Press v. Thornburgh, 868 F.2d 1285, 1295 n.12 (D.C. Cir.), cert. granted, 109 S. Ct. 1952 (1989). The District of Columbia Court of Appeals, however, dismissed this view as improperly relying on "the notion of a 'deep pocket' supporting the paper, which is an impermissible consideration under the NPA." Id.

87 See, e.g., 116 Cong. REc. 23,148 (1970) (statement of Rep. McCulloch) (asserting that antitrust exemptions for JOAs "should be limited only to those situations where a joint newspaper operating arrangement is demonstrably essential to prevent a newspaper failure"). This sentiment is particularly relevant when applied to chains. See Note, supra note 32, at 689 ("If a chain owner's efficiencies and economies of scale allow it to operate a newspaper without an actual net financial loss, the alternative of a [JOA] should not be available.").

88 See supra notes 2 \& 3 and accompanying text.

89 See supra note 79.

90 See Note, supra note 32 , at $695-96$ \& $\mathrm{nn} .184-87$ ("The increasing concentration in the newspaper industry thus decreases the diversity of voices in the marketplace, and a select group has increasing influence over the news and ideas that reach the public through their newspapers."); see also B. BAGDIKIAN, supra note 1 , at 84 ("Editorial vigor diminishes under chain ownership."); $c$. Shenefield, supra note 32 , at 1334 ("[P]reserving a large number of independent voices . . . is especially important because the concentration of newspaper ownership limits the diversity of opinion expressed in newspapers and diminishes the opportunity for First Amendment expression . . .."); Media and the First Amendment, supra note 14, at 898 


\section{Incentives for Predation}

The NPA encourages publishers to reap the financial benefits of a JOA by providing loopholes through which newspapers strive to attain failure. Substantial financial rewards motivate competitive newspapers to engage in predatory pricing, ${ }^{91}$ in which one newspaper deliberately lowers prices beneath $\operatorname{costs}^{92}$ in an attempt to drive

("Control of the press, whether by government or by private entrepreneurs, conflicts with the public interest in receiving information and ideas.").

91 See supra note 21 for an explanation of the financial rewards characteristic of JOAs. Although these benefits also could be accrued under an internal monopoly, one chain cannot drive a newspaper owned by another chain out of business because both can support their losses with profits earned by monopoly papers elsewhere in the chain. See supra text accompanying note 83 .

92 A newspaper's total economic costs include "fixed costs," usually consisting of plant, equipment, and machinery, which do not vary with changes in output, and "variable costs," such as materials, fuel, and direct and indirect labor, which correspond to changes in output. See P. AREeda \& D. Turner, supra note $21, \S 712$, at 154-55. Because of the substantial initial investment in plant and machinery, the newspaper industry "is characterized by very high fixed costs and [comparatively] very low variable costs, which create significant production economies of scale." Busterna, supra note 83 , at 6 . The increase in the total costs caused by producing an additional unit of output is the "marginal cost." See P. AREEDA \& D. TURNER, supra note $21, \S 712$, at 155 . A business may be held to have engaged in predatory pricing if it sets prices below either marginal costs, see id. at 168, or average variable costs, see id. at 174 . See also infra note 93 for further discussion of what constitutes predatory pricing.

The newspaper industry is also unique in that revenue is obtained through both newspaper sales and advertising. Lowering prices beneath costs could consequently refer either to the price of advertisements or to the price of the newspaper. Both tactics appear to have been employed in the Detroit price war, which has been characterized by "low advertising rates and ... a an extraordinarily low copy price." Busterna, supra note 83 , at 16 . However, because "[i]t is a well established fact that the life blood of the newspaper business is its advertising revenue," City \& County of Honolulu v. Hawaii Newspaper Agency, 559 F. Supp. 1021, 1030 (D. Haw. 1983), a newspaper may achieve a greater predatory impact by concentrating its attention on advertising rates.

Newspapers that have a substantial circulation advantage reap the benefits of the special relationship between circulation and advertising rates:

Rates are normally quoted in terms of the cost to reach one million readers with a single line of advertising copy - the "milline" rate. This practice means that, where two papers charge the same amount per line, the paper with the larger circulation can quote a lower milline rate. When one paper has a circulation dramatically larger than its competitors', it is able to charge more per line, yet still quote a higher milline rate. Because businessmen want the most for their advertising dollar, the smaller paper is at a distinct competitive disadvantage.

Media and the First Amendment, supra note 14, at 894 (citing Roberts, Antitrust Problems in the Newspaper Industry, 82 HaRv. L. REv. 319, 324 (1968)). Although the smaller paper could attempt to match the larger paper's circulation by lowering its advertising 
a rival out of business. ${ }^{93}$ That competitor willingly tolerates shortterm losses in anticipation of the profits generated by a long-term monopoly. ${ }^{94}$ Because of the substantial lag before the realization of profits, predation occurs only in unusually conducive circumstances: ${ }^{95}$ the antitrust exemption permitted under the NPA has been cited as "the necessary ingredient that can make predation successful." 96

Under the NPA, the goal of predatory pricing is not to drive the competitor out from the market but rather to drive that competitor

rates, it would encounter difficulties in absorbing the temporary losses necessary to achieve an equalization of the milline rate. See id. at 895-96.

93 See Busterna, supra note 83 , at 4 . There is presently no consensus on the proper definition of predatory pricing in the antitrust context. See Cargill, Inc. v. Monfort of Colorado, Inc., 107 S. Ct. 484, 493 n.12 (1986). The Supreme Court, in Matsushita Elec. Indus. Co. v. Zenith Radio, 475 U.S. 574 (1986), indicated that predatory pricing would be found upon a showing of a conspiracy to drive the alleged victim out of the relevant market by "(i) pricing below the level necessary to sell their products, or (ii) pricing below some appropriate measure of costs." Id. at 585 n.8. There is a wide split among circuit courts as to what constitutes an "appropriate measure;" some have held that predation may be presumed only upon a showing of pricing below marginal or average variable costs, see Arthur $\mathrm{S}$. Langenderfer, Inc. v. S.E. Johnson Co., 729 F.2d 1050, 1056 (6th Cir.), cerl. denied, 469 U.S. 1036 (1984), while others have claimed that even pricing above average total costs may constitute predation if predatory intent is proven. See Transamerica Computer Co. v. IBM Corp., 698 F.2d 1377, 1387 (9th Cir.), cert. denied, 464 U.S. 955 (1983).

The Matsushita Court also stated that because of the time delay and heavy losses inherent in driving a competitor out of the market, predatory pricing is impractical and rarely employed. See Matsushita, 475 U.S. at 589. This argument does not encompass competitive newspapers: the amount of time needed to convince a paper to conspire to meet the standard of failure necessary for a JOA is significantly less than that needed to make the other newspaper close permanently.

94 See Matsushita, 475 U.S. at 588. The Matsushita Court stated that because it is unlikely that a predator will accrue and maintain monopoly power over an extended period of time, "there is a consensus among commentators that predatory pricing schemes are rarely tried, and even more rarely successful." Id. at 589 (citations omitted). The Court noted, however, that a predatory scheme's chances of success are greatest when there is a high barrier to entry that enables the predator "to maintain supracompetitive prices for an extended time." $I d$. at $591 \mathrm{n} .15$. Because the newspaper industry is characterized by heavy costs and high financial barriers to entry, see supra text accompanying notes 13-14, the reasoning in Matsushita is inapplicable to JOAs.

95 See Busterna, supra note 83, at 5.

96 Id. at 9; cf. Michigan Citizens for an Indep. Press v. Attorney Gen., 695 F. Supp. 1216, 1221 (D.D.C. 1988) ("[W]henever government offers a benefit because of financial hardship-be it welfare applicant or failing newspaper-there is always an incentive for the potential recipient to either exaggerate or exacerbate its woes in order to receive the benefit."), aff'd sub nom. Michigan Citizens for an Indep. Press v. Thornburgh, 868 F.2d 1285 (D.C. Cir.), cert. granted, 109 S. Ct. 1952 (1989). 
into a JOA. ${ }^{97}$ As such, the NPA provides incentive for publishers to conspire with each other and pursue strategies to bring one of their newspapers under the statutory umbrella of "failure." 98 Despite the NPA's guarantee that " $[n]$ othing contained in the chapter shall be construed to exempt from any antitrust law any predatory pricing [or] any predatory practice,"99 significant evidence establishes that such tactics have in fact been employed. The facts and circumstances surrounding the recent Detroit JOA, for example, indicate that the publishers in that city engaged in a "conspiracy of cooperation" prior to the agreement. ${ }^{100}$

Detroit is presently the only metropolitan area outside of New York with two independent general-interest daily newspapers, each of whose circulation surpasses $650,000 .^{101}$ The competitors-the Detroit Free Press and The Detroit News-were immersed in a cutthroat price and wage war for more than twenty years preceding the JOA. ${ }^{102}$ Detroit citizens and advertisers consequently enjoyed the least expensive major dailies and the highest per capita newspaper readership rate of any major metropolitan area in the nation. ${ }^{103}$

Gannett acquired the News in 1985; shortly thereafter it entered into discussions with Alvah H. Chapman, Jr., chairman of KnightRidder (which owned the Free Press), about the possibility of a

97 See Busterna, supra note 83 , at 13.

98 Such a conspiracy is prohibited by $\S 1$ of the Sherman Act, 15 U.S.C. $\S 1$ (1982), which declares illegal "[e]very contract, combination in the form of trust or otherwise, or conspiracy, in restraint of trade or commerce . ..."

A newspaper may meet the statutory definition of failure long before its demise becomes inevitable. A conspiracy to meet the statutory definition of failure is particularly effective when the proposed JOA is between newspapers owned by chains. A chain acting as "predator" may use earnings from profitable newspapers elsewhere within the chain to offset the losses sustained from its "predatory" tactics. See supra text accompanying notes 83-84. If the victim newspaper is also a chain, however, it may employ similar techniques and extend the predatory battle indefinitely. The predation argument is therefore valid in either of the two following scenarios: (1) a situation in which the predator is a member of a chain but the victim is not, see Busterna, supra note 83 , at 15 , or (2) a conspiracy between two newspapers which are either members of chains or otherwise able to sustain substantial losses over extended periods of time. See supra text accompanying note 84 .

9915 U.S.C. $\S 1803$ (c) (1982).

100 Busterna, supra note 83, at 13.

101 See Michigan Citizens, 695 F. Supp. at 1217.

102 See id.

103 See id. Shortly after the Attorney General's approval of the Detroit JOA, Gannett announced its intent to cut prices in Little Rock, Arkansas, where it is presently in competition with an independent newspaper. See NPA Oversight Hearing, supra note 42 (statement of W. Edward Wendover, Editor and Publisher, The Community Crier, Plymouth-Canton, Michigan, at 2). 
JOA. ${ }^{104}$ The ensuing relationship between the allegedly competing newspapers was described by one unspecified Knight-Ridder spokesman as "brotherly." 105 This characterization illustrates two critical flaws inherent in the NPA: failure to preserve true competition between newspapers and incentive to engage in predation in order to qualify for a JOA. ${ }^{106}$

\section{Incentives to Manipulate Financial Failure}

The NPA requires only that one of the newspapers seeking to enter a JOA be "in probable danger of financial failure." 107 This standard is far less stringent than that espoused in Citizen Publishing Co. v. United States, ${ }^{108}$ because it fails to specify what factors should be considered in determining whether a newspaper's "failure" is sufficiently imminent to warrant the drastic option of a JOA. ${ }^{109}$ Publishers consistently have argued for the widest possible latitude in interpreting the definition, and numerous JOAs have accordingly received approval even though they were far from the "last resort" envisioned by the NPA's proponents.

104 See Busterna, supra note 83, at 13. Knight-Ridder had apparently made similar overtures to the prior owners of the News, without apparent success. See id. at 13-14.

105 See id. at 14. This "brotherly" relationship may have been inspired by the potential profitability of a JOA: approval of the Detroit JOA would allow KnightRidder and Gannett to split as much as $\$ 100$ million in annual profits within six years. See Justices to Hear Newspaper Case, Phila. Inquirer, May 2, 1989, at C2, col. 5.

106 While no concrete proof exists that the Detroit newspapers were pricing below short-term costs within the meaning of "predatory," a "powerful presumption" may be inferred from the facts that:

a. Both newspapers sustained heavy losses $-\$ 35$ million for the Free Press and $\$ 20$ million for the News over five years - while increasing costs and holding down circulation and advertising prices.

b. " $[\mathrm{B}]$ oth newspapers . . . slipped off the advertising rate card, a practice not normally done with print advertising media."

c. Chain owners in both circumstances were able to sustain papers through the use of profits from monopoly papers elsewhere in the chain.

See Busterna, supra note 83 , at 14 .

10715 U.S.C. § $1802(5)$ (1982).

108394 U.S. 131 (1969). Citizen Publishing required that the company be on the verge of liquidation and that there be no prospective buyers other than its competitor. See Media and the First Amendment, supra note 14, at 903; see also supra text accompanying notes 23 \& 24 .

109 Factors that should generally be considered in determining if a company is in danger of failure are: "the unhealthy conditions of the firm, the dangers these conditions pose for the future, the feasibility of curative measures short of merger, and the healthy aspects of the firm." Media and the First Amendment, supra note 14, at 901-02 (citing United States v. Third Nat'l Bank, 390 U.S. 171, 187 (1969)). 
In Committee for an Independent P-I v. Hearst Corp., ${ }^{110}$ the Ninth Circuit Court of Appeals reversed a district court ruling and upheld the Attorney General's approval of a JOA between Seattle's Times and Post-Intelligencer. The court reached its decision despite evidence that the Hearst Corporation, which owned the Post-Intelligencer, had received and ignored seven purchase inquiries. ${ }^{111}$ The court acknowledged, however, that the presence of alternative buyers was a valid factor to be considered in evaluating a newspaper's eligibility for a JOA: "While we disagree with the district court's conclusion that an attempt to sell the paper is necessary to prove no reasonable alternatives to the JOA exist, we do agree that reasonable alternatives to a JOA are relevant to our analysis."112

The Hearst Corporation's failure to consider selling the paper suggested that it deliberately sustained losses in order to qualify for a JOA. Although the Hearst court expressed concern that newspapers not deliberately "engage in poor business practices or maintain inept personnel" solely to qualify for a JOA in the future ${ }^{113}$ and recognized that " $[t]$ he pertinence of interested purchasers . . . may require a JOA applicant to prove that the 'new ownership and management could not convert the [paper] into a profitable enterprise without resort to a joint operating arrangement," "114 it upheld the approval of the Seattle JOA. The Court based its decision on findings that the Post-Intelligencer was deeply immersed in a "downward spiral" and that the JOA's proponents had sufficiently established "that the paper was managed reasonably and its trend toward failure [was] irreversible under any management." 115

In evaluating the proposed JOA in Detroit, the Court of Appeals for the District of Columbia employed a standard even more easily satisfied than that of the "downward spiral." In Michigan Citizens for an Independent Press $v$. Thormburgh, ${ }^{116}$ the court upheld former Attorney General Edwin Meese's grant of a JOA between the Detroit Free Press and the The Detroit News, despite Meese's acceptance of the ALJ's finding of fact that neither paper had entered a downward spi-

110704 F.2d 467 (9th Cir.), cert. denied, 464 U.S. 892 (1983).

111 See id. at 475 \& n.5.

112 Id. at 476.

113 Id. at 478 .

114 Id. (quoting Recommended Decision of Administrative Law Judge Moore on the Application of the Cincinnati Enquirer and the E.W. Scripps Co., Dep't of Justice Docket No. 43-03-24-4, at 127 (1979)).

115 Id. at 479 .

116868 F.2d 1285 (D.C. Cir.), cert. granted, 109 S. Ct. 1952 (1989). 
ral. ${ }^{17}$ By condoning a JOA in the absence of a showing of overriding need, the Michigan Citizens court effectively removed any conceivable barriers to future JOAs.

The Michigan Citizens court disregarded the Hearst court's mandate to consider the availability of reasonable alternatives before sanctioning a JOA. Although no ready purchasers existed, the ALJ discerned a "reasonable alternative": "Detroit could sustain two profitable papers if the Free Press and the News both raised circulation and advertising prices."118 When coupled with the substantial evidence that the Free Press's losses were purposefully induced, ${ }^{119}$ this indication of potential profitably establishes that a JOA was not the only viable option.

The Michigan Citizens court applied extreme deference in reviewing the Attorney General's decision and declared that it could overturn that decision only if it was clearly "arbitrary or capricious."120 The legislative history of the NPA, however, indicates that JOAs were intended to serve only as final resorts; the Michigan Citizens court's failure to recognize and sustain this intent has created an "open door" through which "the few remaining competitive U.S. papers [may] merge and reap monopoly profits at the expense of subscribers and advertisers." 121

On November 13, 1989, the Court upheld the proposed JOA in Michigan Citizens by a four-to-four vote. ${ }^{122}$ Because a tie vote in the Supreme Court serves only to resolve a specific dispute and does not

117 Meese conceded that there were no "marketplace declines in overall advertising and newspaper circulation in Detroit of the sort that traditionally propel a junior newspaper into the proverbial 'downward spiral' that is fatal to survival." In re Application by Detroit Free Press, Inc., and the Detroit News, Inc., for Approval of a Joint Newspaper Operation Arrangement Pursuant to the Newspaper Preservation Act, Op. Att'y Gen. No. 44-03-24-8, reprinted in 55 Antitrust \& Trade Reg. Rep. (BNA) 257, 258 (August 11, 1988).

118 Michigan Citizens, 868 F.2d at 1290.

119 See supra text accompanying note 84.

120 See Michigan Citizens, 868 F.2d at 1291 (" [T] that if the Attorney General's statutory interpretation is reasonable, it is entitled to deference ....").

121 White \& Wermiel, supra note 29 , at B5, col. 6 . The JOA application recently filed between two competing newspapers in York, Pennsylvania follows the lead of the Detroit newspapers in asserting that a downward spiral is not a necessary prerequisite for a JOA. See id.

122 See Greenhouse, Linkup of 2 Detroit Papers Upheld by Court in Tie Vote, N.Y. Times, Nov. 14, 1989, at D1, col. 1. Justice Byron White did not participate in the decision. See id. 
establish a general precedent, the standard of approval for JOAs remains open to interpretation. ${ }^{123}$

\section{Violation of First Amendment Rights}

\section{A. The Unconstitutionality of Enforcing the Conditions Imposed by the NPA}

1. The Inevitability of Governmental Interference with Editorial Judgment

The NPA permits exemption from the antitrust laws on the condition that "there is no merger, combination, or amalgamation of editorial or reportorial staffs, and that editorial policies be independently determined." 124 Because no JOA has yet been challenged as violative of this provision, the requirement of "editorial independence" has not officially been defined. Furthermore, neither the NPA nor the regulations promulgated under it specify means through which the Department of Justice may enforce this provision. ${ }^{125}$

The government's ability to enforce the NPA hinges upon the interpretation of this provision. One potential definition of "independence" as requiring only that no one person serve on the editorial boards of both newspapers, does not necessitate investigation into editorial judgment and may accordingly pass constitutional muster. ${ }^{126}$ An alternative definition requires that the papers act inde-

123 Cf. id. at D20, col. 4. (noting that Michigan Citizens "had been expected to produce some guidance about the standards [of failure required for granting JOAs]").

12415 U.S.C. $\S 1802(2)$ (1982) (emphasis added).

125 See id.; 28 C.F.R. \& 48.3 (1988).

126 In the course of ordinary business dealings, a showing that two discrete organizations maintain separate personnel would likely give rise to the assumption that those organizations operate independently. Because of first amendment concerns, however, an assumption that automatically applies to general businesses may not blindly be applied to newspapers. See, e.g., City of Lakewood v. Plain Dealer Publishing Co., 108 S. Ct. 2138, 2146 (1988) (holding that although an ordinance giving the mayor unbridled discretion over permits to soda vendors was constitutional, an identical ordinance governing permits to newspaper publishers was not); Wulp v. Corcoran, 454 F.2d 826, 834 (1st Cir. 1972) (holding unconstitutional a city ordinance requiring street vendors selling certain articles, including newspapers, to obtain permits because the objective of controlling traffic could be achieved without restricting first amendment rights); Philadelphia News, Inc v. Borough Council, 381 F. Supp. 228, 241 (E.D. Pa. 1974) (“[N]ewspaper vending boxes or machines along public streets and sidewalks are a constitutionally protected means of distribution."); $c f$. infra note 138 (contrasting the government's strict stance against regulations governing newspapers with its willingness to sanction regulations governing broadcast media). This line of reasoning suggests that even the mere 
pendently in formulating editorial policy; enforcement of this interpretation invites unconstitutional governmental inquiry into the editorial process because of the inevitable comparison of the newspapers' news and editorial content. The NPA's broad language and clear legislative intent strongly support the latter interpretation.

The language of the proviso explicitly distinguishes the requirement of separate editorial and reportorial staffs from the requirement of independent determination of editorial policy. ${ }^{127}$ Enforcement of the entire provision would consequently transcend mere comparison of the mastheads and additionally entail government inquiry into editorial judgment and decision-making. ${ }^{128}$ This reading appears consistent with interpretations by the Attorney General and federal courts; the Seattle JOA has been interpreted as requiring each newspaper to "retain control over its own editorial policies and news content," 129 while the Detroit JOA has been described as providing "that the news and editorial staffs of the two papers are to remain independent and insulated from influence by the other party to the arrangement." 130 The Government cannot

comparison of personnel, which may suffice for business purposes, would not satisfy the level of independence required by the NPA.

127 See supra text accompanying note 124. An editorial staff is the board of editors who oversee the news operations of a newspaper. Editorial policy is the series of decisions made by the editorial staff. See generally J. Hulteng, The OpInion Function: Editorial and INTERPRETIVE Writing for the News Media 25-39 (1973) (describing the editorial staff and its role in the formulation of editorial policy). A close reading of the statutory language clarifies the congressional intent underlying the proviso. When Congress drafted the NPA, the word "independently" was not used in conjunction with the requirement of discrete editorial and reportorial staffs, but rather to describe the requirement of policy determination. If Congress had intended the requirement to mean only independent editorial staffs, rather than both independent staffs and independent policy determinations, then it would have used the word "independently" only to modify "staffs" and would not have incorporated it into the requirement governing editorial policies.

128 See Media and the First Amendment, supra note 14, at 902 ("The . . . important requirement of editorial and reportorial autonomy is constitutionally limited to only the most superficial enforcement. Although the agreement between the joining papers and the physical integrity of each paper's editorial staff is a proper area of investigation, any government[al] inquiry into editorial content itself is prohibited by the first amendment. This limited scope of inquiry leaves the public interest virtually unprotected."); see also Randolph \& Behr, supra note 58, at A11, col. 5 ("[T]he law does not, and constitutionally could not, stipulate what kind of editorial voices should be preserved under a JOA." (quoting newspaper analyst John Morton)).

129 Notice of application for approval of JOA filed to Attorney General by Seattle Times and Seattle Post-Intelligencer, 46 Fed. Reg. 22,996 (1981).

130 Michigan Citizens for an Indep. Press v. Thornburgh, 868 F.2d 1285, 1289 (D.C. Cir.), cert. granted, 109 S. Ct. 1952 (1989). The proposition of insulated editorial and reportorial staffs is analogous to the concept of "Chinese walls" commonly employed by investment banking firms. A "Chinese wall" isolates a firm's 
determine the independence of editorial policymaking and, in particular, the presence of undue influence prohibited by the Detroit JOA without intruding into editorial judgment and abridging a newspaper's first amendment rights.

Even a seemingly objective comparison of the contents of the two newspapers entails implied assumptions about the reporting techniques and editorial decisions precipitating the selection and ordering of stories, columns, and editorials, thereby effectively constituting impermissible discovery into editorial judgment. ${ }^{131}$ The three criteria employed in studies measuring the independence of JOAs-news space allocation, editorial space allocation, and money spent on news and editorial expenses-all necessitate such unconstitutional government entry into the editorial process. ${ }^{132}$ Similarly, independent policies may not immediately be inferred upon a showing of opposing editorial points of view: such a comparison not only

trading side from its investment banking side, with the intent of "prohibiting the interdepartmental flow of information." Slade v. Shearson, Hammill \& Co., 517 F.2d 398, 401, (2d Cir. 1974); see also Geisler v. Wyeth Lab., 716 F. Supp. 520, 526 (D. Kan. 1989) (discussing the insulation function of a Chinese wall); MacMillano, Inc. v. American Express Co., I25 F.R.D. 71, 74-75 (S.D.N.Y. 1989) (describing the Chinese wall policies of an investment banking firm); Koppers Co. v. American Express Co., 689 F. Supp. 1413, 1416 \& n.5 (W.D. Pa. 1988) (defining the basic function of "Chinese walls" and listing SEC reports that refer to the concept).

131 Further enforcement complications arise when, as in the Detroit JOA, the joining newspapers agree to publish only one paper on Saturday and Sunday, "with each paper assuming separate editorial and news responsibilities" and separate editorial pages. See Michigan Citizens, 868 F.2d at 1289. The newspapers operating under the San Francisco JOA, the Chronicle and the Examiner, also "jointly publish a unified Sunday edition," Bay Guardian Co. v. Chronicle Publishing Co., 344 F. Supp. 1155, 1157 (N.D. Cal. 1972). The determination of independent editorial operations is substantially more difficult to enforce when only one newspaper is published by the jointly operated companies; although the editorial operations are separate, the selection and placement of news stories entail at least some cooperative decision making. The inherent enforcement difficulties created in such an instance suggest that a JOA that permits the two newspapers to publish one joint edition on a regular basis may be beyond the scope of the NPA, in which Congress expressly sought to preserve editorial diversity by ensuring the continued publication of two discrete newspapers. A JOA that permits such a joinder conceivably could be challenged on purely statutory grounds as violating the NPA, without recourse to a constitutional challenge against the Act as authorizing a violation of first amendment rights.

132 See Lacy, Content of Joint Operation Newspapers, in Press ConCENTRATION AND Monopoly: New Perspectives on Newspaper OWNership and Operation 153 (1988). Because no JOA has ever been challenged on the grounds that the newspapers involved were not sufficiently independent, it is impossible to surmise definitively what criteria would be employed by a court or an administrative body in deciding such a challenge. However, because these criteria are the three types of allocation processes assumed by experts "to affect the content of newspapers," id., they arguably represent the most appropriate means of estimating independence. 
comprises an unconstitutional regulation of content ${ }^{133}$ but also overlooks the potential for newspapers to collude and adopt deliberately antagonistic positions. ${ }^{134}$

Such governmental inquiry into editorial judgment or policy deliberations inherently violates the first amendment. In Miami Herald Publishing Co. $v$. Tormillo, ${ }^{135}$ the Supreme Court invalidated a Florida statute that required a newspaper to afford a right of reply to candidates whose personal character had been attacked in its editorials. The Court acknowledged the legitimate need to protect editorial diversity given the newspaper industry's increasingly monopolistic tendencies ${ }^{136}$ but subordinated that interest to the weightier and more deeply-rooted constitutional protection against governmental interference with editorial judgment. ${ }^{137}$ The Tomillo Court emphasized that the Constitution protected those specific activities that would be subject to governmental scrutiny under the NPA:

The choice of material to go into a newspaper, and the decisions made as to limitations on the size and content of the paper, and treatment of public issues and public officials - whether fair or unfair - constitute the exercise of editorial control and judgment. It has yet to be demonstrated how governmental regulation of this crucial process can be exercised consistent with First Amendment guarantees of a free press as they have evolved to this time. ${ }^{138}$

133 See, e.g., Arkansas Writers' Project, Inc. v. Ragland, 481 U.S. 221 (1987) (holding that a state sales tax scheme exempting certain publications, such as newspapers and religious journals, but taxing other publications, such as general interest magazines, was violative of the first amendment because the government cannot impose a content-based discriminatory tax burden on the press); Miami Herald Publishing Co. v. Tornillo, 418 U.S. 241 (1974) (holding that a "right of reply" statute was an unconstitutional regulation of the press' independent editorial process, as well as a content-based penalty imposed on the press that is likely to produce a chilling effect).

134 See supra note 56 and accompanying text.

135418 U.S. 241 (1974).

136 See id. at 248-54.

137 See id. at 258. The prohibition against governmental interference with editorial judgment espoused in Tormillo clearly precludes any enforcement of the NPA that entails comparison of the content of the two newspapers. The reasoning in Tornillo additionally implies that the Constitution would prohibit the government from enforcing any interpretation of the NPA that requires more than a mere comparison of staffs. See id.

138 Id. The Court's strict construction of the first amendment as it applies to the protection of newspapers from government interference is particularly noteworthy when contrasted with the Court's willingness to apply the fairness doctrine to safeguard editorial diversity of the broadcast media. In Red Lion Broadcasting Co.v. FCC, 395 U.S. 367 (1969), the Court upheld an order of the Federal Communications Commission requiring a radio station to provide equal response time to any person attacked in a broadcast. The Red Lion Court indicated, however, 
The sanctity of the newsgathering and editorial processes is deeply embedded in the Constitution and epitomizes the Framers' ideal of a press sufficiently removed from governmental coercion to check government power. ${ }^{139}$ Any potential for government intervention into editorial operations inherently chills the complete freedom necessary for the press to effectuate this function: "[T]he threat of sanctions may deter the . . . [exercise of first amendment freedoms] almost as potently as the actual application of sanctions."140 Concern that enforcement of the NPA would infringe upon freedom of the press permeated the legislative debate over the Act: one representative warned of the potential for "Government regulation of newspapers, a loss of editorial independence, and a compromising of the traditional independence of the American press [that] could do irreparable damage to our political, economic, and social fabric."141

\section{The Unconstitutionality of Government Entry into the Newsroom}

The potential chill created by government "entry" into the newsroom, even for motives unrelated to the suppression of speech, has generally prompted governmental reluctance to "enter" the

that this doctrine did not extend to newspapers because the Court did not perceive the press as a scarce resource warranting governmental regulation. The scarce number of potential broadcast media sources made it "idle to posit an unabridgeable First Amendment right to broadcast comparable to the right of every individual to speak, write, or publish." Id. at 388.

The Court has consistently invoked this "scarcity" rationale in differentiating broadcast media from newspapers. See, e.g., Columbia Broadcasting Sys. v. Democratic Nat'l Comm., 412 U.S. 94, 101 (1973) ("Unlike other media, broadcasting is subject to an inherent physical limitation. ..."); see also FCC v. League of Women Voters, 468 U.S. 364, 376 (discussing a statute forbidding editorializing by noncommercial educational stations receiving public grants and noting that "[w]ere a similar ban on editorializing applied to newspapers and magazines, we would not hesitate to strike it down as violative of the first amendment"), appeal dismissed, 468 U.S. 1205 (1984); FCC v. National Citizens Comm. for Broadcasting, 436 U.S. 775, 800 (1978) (holding that regulation of broadcasting "may be permissible where similar efforts to regulate the print media would not be").

139 See Anderson, The Origins of the Press Clause, 30 UCLA L. Rev. 455, 534 (1983) ("As a means of checking government power ... the press was expected to be the primary source of restraint.").

140 NAACP v. Button, 371 U.S. 415, 433 (1962). The lack of any official definition or clearly identifiable criteria of editorial independence may magnify any potential chill on the free press because there is no authoritative source to which editors can turn as a safe harbor when threats of sanctions arise. See supra text accompanying notes 124-25.

141116 Cong. REC. 23,167 (1970) (statement of Rep. Edwards). 
newsroom for any reason. In implementing the Privacy Protection Act of 1980 ("PPA"), ${ }^{142}$ Congress severely limited the government's power to enter newsrooms when conducting searches and seizures pursuant to a criminal investigation. The PPA prohibits all government entry to search for or seize work product materials possessed by newspaper persons, authors, or broadcasters, except when there is probable cause to believe that the person possessing the materials has committed or is committing a criminal offense involving the materials or when there is reason to believe that immediate seizure of the materials is essential to prevent death or serious bodily injury. ${ }^{143}$ Even if the government has reason to believe that the person possessing the material has committed or will commit a crime, however, government officials may not search for or seize workproduct materials if the alleged offense "consists of the receipt, possession, communication, or withholding of such materials or the information contained therein." 144

The PPA was passed less than three years after the Supreme Court's decision in Zurcher $v$. Stanford Daily. ${ }^{145}$ The Zurcher Court held that the first amendment did not preclude searches and seizures in newsrooms conducted pursuant to the "probable cause" requirement of the fourth amendment. ${ }^{146}$ Although Zurcher has not been expressly overruled, its holding was severely limited by the passage of the PPA. ${ }^{147}$ The PPA appears instead to have followed Justice Stewart's dissent in Zurcher, which warned that "unannounced police

14242 U.S.C. $\$ \S 2000$ aa to aa-12 (1982).

143 See id. at $\$ 2000 \mathrm{aa}(\mathrm{a})$. Section $2000 \mathrm{aa}(\mathrm{b})$ discusses the more lenient restrictions governing searches and seizures of non-work product material.

144 Id. at $\$ 2000$ aa(a)(1).

145436 U.S. 547 (1978).

146 See id. at 567 ("[W]e decline to reinterpret the [Fourth] Amendment to impose a general constitutional barrier against warrants to search newspaper premises ....").

147 The PPA represents Congress' attempt to restrict the broad scope of Zurcher. See Seek Help Immediately to Block Search, News Media \& L., Fall 1988, at 6. The Zurcher decision represented judicial acknowledgment of the government's full constitutional power to conduct searches pursuant to the fourth amendment. In enacting the PPA, Congress sought to restrict that power to limited situations involving the probable culpability of members of the press. By statutorily limiting the government's right to conduct searches and seizures of the press, Congress granted greater protection than the Constitution requires for the protection of the editorial process from unwarranted governmental intrusion. See, e.g., S. REP. No. 874, 96th Cong., 2d Sess. (stating that the purpose of the bill is "to limit governmental search and seizure of documentary materials possessed by persons engaged in first amendment activities"), reprinted in 1980 U.S. CODE CONG. \& ADMIN. News 3950, 3950; id. at 3950-51 "This [bill] was prompted by Zurcher ... . The committee believes that the search warrant procedure in itself does not sufficiently protect the press and other innocent third 
searches of newspaper offices will significantly burden the constitutionally protected function of the press to gather news and report it to the public."148

The Supreme Court articulated these first amendment concerns in advocating a blanket restriction on economic legislation that "singles out" newspapers for special treatment. In Minneapolis Star E Tribune Co. v. Minnesota Commissioner of Revenue, ${ }^{149}$ the Court invalidated a special "use tax" on the cost of paper and ink products levied only on newspapers using more than $\$ 100,000$ worth of those products. The Court held that any differential treatment of the press was presumptively unconstitutional because it implied motives related to the suppression of speech and potentially chilled first amendment freedoms: "[T]he very selection of the press for special treatment threatens the press not only with the current differential treatment, but also with the possibility of subsequent differentially more burdensome treatment."150

The broad scope of the holding in Minneapolis Star encompassed all legislation "singling out" newspapers, regardless of that legislation's potential harmful or beneficial effect upon newspapers and regardless of the presence or absence of censorial legislative intent. ${ }^{151}$ Minneapolis Star has not been overruled and remains good

parties . . . ."); see also id. at 3956 (noting the probable chilling effect on the press from disruptive governmental searches of newspaper employees and offices).

148 Zurcher, 436 U.S. at 574 (Stewart, J., dissenting). Justice Stewart noted the two most significant potential dangers of newsroom searches: physical disruption of newspaper operations and the possibility of disclosure of information obtained from confidential sources and the identity of those sources. See id. at 571 (Stewart, J., dissenting). Stewart warned that "[s]ince the indisputable effect of such searches will thus be to prevent a newsman from being able to promise confidentiality to his potential sources, . . . a journalist's access to information, and thus the public's, will thereby be impaired." Id. at 572-73 (Stewart, J., dissenting).

149460 U.S. 575 (1983).

$150 \mathrm{Id}$. at 588. The Minneapolis Star Court intimated that the legislation in question need not be burdensome and could even benefit newspapers: "[E]ven without actually imposing an extra burden on the press, the government might be able to achieve censorial effects ...."Id. Any legislation singling out the press for differential treatment could be held presumptively unconstitutional because of its potentially chilling effect on editorial independence. Differential treatment might create a cautionary fear among the press that future burdensome state measures will follow-a fear that can only interfere with the press' constitutional right to serve as an unfettered and independent source of criticism and ideas. See Bezanson, Political Agnosticism, Editorial Freedom, and Government Neutrality Toward the Press: Observations on Minneapolis Star \& Tribune v. Minnesota Commissioner of Revenue, 72 Iowa L. REv. 1359, 1360 (1987).

151 Despite the factual similarity between the two cases, the Minneapolis Star Court expressly did not rely on Grosjean v. American Press Co., 297 U.S. 233 (1936). See Minneapolis Star, 460 U.S. at 579-80. In Grosjean, the Court invalidated a Louisiana 
law; however, many subsequent decisions have adopted narrow interpretations of the Court's holding, thereby limiting its initial expansiveness. ${ }^{152}$

The Supreme Court relied upon its decision in Minneapolis Star in deciding Arkansas Writers' Project, Inc. v. Ragland. ${ }^{153}$ The Ragland Court held unconstitutional a state sales tax scheme that taxed general interest magazines but exempted newspapers and religious, professional, trade, and sports journals. The Court noted, however, that this selective scheme was even "more disturbing" than that in Minneapolis Star, "because the basis on which Arkansas differentiates between magazines is particularly repugnant to First Amendment principles: a magazine's tax status depends entirely on its content."154

The Ragland Court's emphasis on content suggests a possible narrowing of Minneapolis Star's initial scope. ${ }^{155}$ The Ragland Court emphasized that the statute in question employed a content-based distinction and specified a select group of publications for differential treatment; its decision consequently appears more consistent with the Court's second holding in Minneapolis Star that the use tax "violates the First Amendment not only because it singles out the press, but also because it targets a small group of newspapers."156

license tax imposed on all state newspapers whose weekly circulation exceeded 20,000. See Grosjean, 297 U.S. at 240. The Grosjean Court held that because the statute's legislative history indicated that the tax scheme was intended to punish a select group of politically outspoken newspapers, it was unconstitutional as violative of the first amendment. See id. at 250 ("[The tax] is bad because, in the light of its history and of its present setting, it is seen to be a deliberate and calculated device in the guise of a tax to limit the circulation of information to which the public is entitled in virtue of the constitutional guarantees.") The Minneapolis Star Court distinguished Grosjean, noting that "[i]n the case currently before us . . there is no legislative history and no indication ... of any impermissible or censorial motive on the part of the legislature." Minneapolis Star, 460 U.S. at 580. The Minneapolis Star decision consequently does not adopt the premise that proof of an impermissible legislative purpose is a requirement for finding a tax scheme violative of the first amendment. Rather, the decision relies upon the assumption that, although the state acted with proper care and motivation and without manifest censorial intent, the resulting legislation exceeded constitutional bounds because it authorized differential treatment of the press and because such treatment is likely to chill the press' exercise of its first amendment rights.

152 See, e.g., infra note 162 (discussing cases that interpret Minneapolis Star as requiring a compelling state interest to sustain legislation that singles out the press).

153481 U.S. 221 (1987).

154 Id. at 229.

155 See Bezanson, supra note 150, at 1360 ("Ragland's reliance on Minneapolis Star threatens to mask the principles announced earlier and provides lower courts with little guidance for judging the constitutionality of regulatory schemes affecting the press.").

156 Minneapolis Star, 460 U.S. at 591. 
In Minneapolis Star, only newspapers spending more than $\$ 100,000$ were granted the exemption, while in Ragland only special interest magazines were exempt from paying taxes. Because the NPA similarly allows exemptions only to JOAs comprised of newspapers that are "published in one or more issues weekly," 157 it would be held unconstitutional under this rationale.

Lower courts have rejected first amendment challenges based on potential harm to smaller newspapers that are forced to compete with the more powerful newspapers in a JOA. ${ }^{158}$ In Bay Guardian Co. v. Chronicle Publishing Co., ${ }^{159}$ the court refused to find a first amendment violation on the ground that the NPA did not actively authorize conduct but merely served as a limited repeal of the antitrust laws. ${ }^{160}$ Bay Guardian was decided more than ten years before Minneapolis Star and Ragland; ${ }^{161}$ a court addressing a similar challenge today would likely require at least a compelling state interest to sustain the disputed statute. $^{162}$

157 15. U.S.C. § 1802(4) (1982).

158 See Committee for an Indep. P-I v. Hearst Corp., 704 F.2d 467, 482 (9th Cir.), cert. denied, 464 U.S. 892 (1983); Bay Guardian Co. v. Chronicle Publishing Co., 344 F. Supp. 1155, 1158 (N.D. Cal. 1972). For a more in-depth discussion of the financial problems faced by a JOA's smaller competitors, see infra notes $170-79$ and accompanying text.

159344 F. Supp. 1155 (N.D. Cal. 1972).

160 See id. at 1157-58.

161 Although Hearst was decided two months after the Supreme Court handed down its decision in Minneapolis Star, the Hearst court did not cite Minneapolis Star and appears to have either ignored or been unaware of its relevance. Instead, the Hearst court relied heavily upon Bay Guardian in determining that the JOA in question did not violate first amendment rights. See Hearst, 704 F.2d at 482-83. The Hearst court additionally claimed that there was no first amendment violation because the NPA's exemption would in no way affect the content of the smaller newspaper's speech. See id. at 483. This argument ignores the NPA's potential to chill the speech of the larger newspapers involved in a JOA. See infra notes $164-69$ and accompanying text.

Bay Guardian was decided 11 years before Minneapolis Star. It is unlikely that the NPA would survive first amendment scrutiny as defined by the Minneapolis Star Court. Minneapolis Star declared that "[a] tax [and implicitly any legislation] that burdens rights protected by the First Amendment cannot stand unless the burden is necessary to achieve an overriding governmental interest." Minneapolis Star, 460 U.S. at 582. Had the Bay Guardian court applied this strict scrutiny of review, it would have inquired whether the Act had exceeded permissive bounds in achieving its avowed purpose. The Bay Guardian court instead evaluated the plaintiff's claim of overbreadth using a mere rationality test, see Bay Guardian, 344 F. Supp. at 1155; the Minneapolis Star Court's implication of first amendment rights would compel the Bay Guardian court to apply strict scrutiny to this claim.

I62 Although the Minneapolis Star Court condemned legislation that singles out the press for special treatment, it intimated that such legislation would be upheld if a sufficiently compelling government interest could be articulated. See Minneapolis Star, 460 U.S. at 586-90. Lower courts citing Minneapolis Star have recognized that a 
Despite the present ambiguity, the principles underlying Minneapolis Star remain a vital component of any evaluation of economic legislation directed at newspapers. The Minneapolis Star Court based its decision upon its concern that differential treatment of newspapers threatens the operation of a free press and ultimately hinders the unfettered exchange of ideas; ${ }^{163}$ the "threat of burdensome taxes" imposed solely on the press could operate "as effectively as a censor to check critical comment by the press, undercutting the basic assumption of our political system that the press will often serve as an important restraint on government." 164 The Court thus invalidated the statute because governmental power to confer a harm or benefit may lead newspapers to exercise extreme caution and ultimately may chill the free expression of editorial opinion.

This concern was recently reiterated by the Court in City of Lakewood v. Plain Dealer Publishing Co. ${ }^{165}$ The Lakewood Court held unconstitutional an ordinance allowing the Mayor of Lakewood unbridled discretion to grant or deny permit applications to publishers seeking

narrowly tailored means to achieve a compelling state interest is necessary to justify special regulation of speech. See, e.g., Smith v. Butterworth, 866 F.2d 1318, 1320 (11 th Cir.) ("Even where a sufficiently compelling state interest can be shown, those arguing in favor of a regulation's validity must further demonstrate that its goal cannot be achieved by means that do not infringe as significantly on first amendment rights."), petition for cert. filed, 57 U.S.L.W. 3828 (May 26, 1989) (No. 88-1993); Hornstein v. Hartigan, 676 F. Supp. 894, 896 (C.D. Ill. 1988) ("Although general economic regulation of the press is permissible, differential taxation based on content is valid only if the state can show that the regulation serves a compelling state interest and is narrowly tailored to serve that interest.").

The NPA was allegedly passed to serve the governmental interest of "maintaining a newspaper press editorially and reportorially independent and competitive in all parts of the United States." 15 U.S.C. $\S 1801$ (1982). Although the preservation of independent news voices is a significant interest, it is not sufficiently compelling to outweigh the danger posed to existing free voices. Furthermore, the NPA may be construed as a roundabout attempt to equalize voices, which is precisely the type of conduct the Supreme Court prohibited in Buckley v. Valeo, 424 U.S. 1 (1976). See infra text accompanying notes 193-94 (discussing the Court's reasoning in Buckley). This interest also becomes less compelling in light of the NPA's general failure to achieve its avowed goals. See supra notes 47-66 and accompanying text. Even if the governmental goals were sufficiently "compelling" to justify regulation, a law that permitted joinder of business operations but that did not grant exemptions from the antitrust laws would constitute a more narrowly tailored means of achieving those goals. See supra text accompanying notes 36-39.

163 See Minneapolis Star, 460 U.S. at 585. Because, despite its sweeping reach, Minneapolis Star addressed only legislation that "singles out" the press, it is unclear whether a court following Minneapolis Star would be obliged to strike down a general regulation that does not expressly single out the press but is most acutely felt by the press. Such an inquiry is, however, beyond the scope of this Comment.

164 Id.

165108 S. Ct. 2138 (1988). 
to place their newsracks on public property. The Court expressed its fear that newspapers seeking permit approval would refrain from criticizing an incumbent mayor, and invalidated the ordinance for its impermissible interference with the newspapers' content. ${ }^{166}$

Criticisms resembling those made by the Court in Minneapolis Star and Lakewood have been leveled at the NPA. One opponent denounced the relationship between government and newspapers under the NPA as "government-licensed journalism" that "often puts newspapers in bed with government." 167 In a similar vein, the newspapers involved in the proposed JOA in Detroit have been accused of allowing their desire for the approval of their proposed JOA to color their editorial content. This desire allegedly motivated the refusal of the Detroit Free Press to publish editorial cartoons unfavorable to then-Attorney General Edwin Meese during the period in which he was to rule on the proposed JOA. ${ }^{168}$ That "[e]ven a newspaper known for its ethics since the days of Jack Knight, stoops to prostitution as it embarrassingly begs for governmental blessing," 169 suggests that, like the ordinance in Lakewood and the use tax in Minneapolis Star, the antitrust exemption permitted by the NPA engenders subtle but inevitable government interference with editorial judgment.

166 See id. at 2144 ("It is not difficult to visualize a newspaper that relies to a substantial degree on single issue sales feeling significant pressure to endorse the incumbent Mayor in an upcoming election, or to refrain from criticizing him, in order to receive a favorable and speedy disposition on its permit application.").

167 NPA Oversight Hearing, supra note 42 (statement of Bruce B. Brugman, editor and publisher of the San Francisco Bay Guardian, at 5-6) (presenting examples of alleged cooperation between the newspapers in the San Francisco JOA and the San Francisco city government); see also id. (statement of W. Edward Wendover, Editor and Publisher, The Community Crier, Canton, Michigan, at 2) (claiming that "the [NPA] is flawed because there is no real way to separate granting JOAs, regulation and enforcement from politics").

168 See Knight, A Sad Story at Knight-Ridder, Wash. Post, Aug. 2, 1988, at C1, col. 2 (accusing Knight-Ridder of "tak[ing] the prize for perfidy" by ordering two editorial cartoonists of the Free Press "to go easy on Meese" during the period in which Meese was considering their JOA application); see also Barnett, The Detroit Newspaper Wars: Competition is Now Up to the Courts, N.Y. Times, Oct. 23, 1988, at C3, col. 1 ("Members and friends of [Knight-Ridder, owner of the Free Press] have watched in dismay as the news pages of The Free Press were commandeered for the publisher's public relations campaign to influence Mr. Meese and as editorial cartoons critical of Mr. Meese were banned."); Pelham, Clifford Defends Media Deal. . . and His Honor, Legal Times, Sept. 12, 1988, at 1 ("Fearful of offending Meese, who would make the final decision on the proposal, editors of the Free Press decided not to run editorial cartoons about the embattled attorney general.").

169 NPA Oversight Hearing, supra note 42 (statement of W. Edward Wendover, Editor and Publisher, The Community Crier, Canton, Michigan, at 3). 


\section{B. Creation of Economic Barriers to Entry}

The legitimacy of the NPA is compromised by its inability to serve its avowed purposes; the Act's dangers extend, however, beyond mere legislative failure. By erecting an almost impenetrable barrier to entry into the newspaper market, the NPA allows publishers involved in a JOA to enjoy monopolistic advantages. ${ }^{170}$ In severely limiting other newspapers' access to the market, the NPA impedes the right to publish guaranteed by the first amendment.

During the Congressional debates over the NPA's passage, one of the principal arguments advanced by the Act's proponents concerned the status of the newspaper industry as a "natural monopoly." 171 By one proponent's own admission, a year before the Act's passage, forty-five cities still enjoyed independent newspaper competition. ${ }^{172}$ Similarly, legislators urging the NPA's passage could point only to an emerging "trend" towards natural monopoly, rather than a complete establishment of such a phenomenon. ${ }^{173}$ Courts evaluating JOAs have been similarly inconclusive in defining the economic structure of the newspaper industry. In Michigan Citizens, for example, the court noted that "[i]t is not at all clear whether the newspaper business in some cities is a natural monopoly, and, if so, in cities of what size." 174

Whether a natural monopoly actually exists in the newspaper

170 See, e.g., 116 Cong. Rec. 23,150 (1970) (statement of Rep. MacGregor) ("Passage of [the NPA] will lessen competition by handicapping the ability of other newspapers to be established, to grow and to provide the public with an independent view of the news."); Busterna, supra note 83, at 10-11 ("The Act allows two newspapers to set 'voluntary' combination rates that virtually close out a third newspaper from the advertising revenue market.").

171 See 116 Cong. REc. 23,148 (1970) (statement of Rep. McCulloch) (justifying the Act as necessary to preserve editorial and reportorial diversity in the face of conditions leading to "a stultifying monopoly on news and opinion"). A natural monopoly market is a market which is more efficiently served by one firm than by two or more firms. For a detailed discussion of the "natural monopoly" phenomenon, see Hazlett, Private Monopoly and the Public Interest: An Economic Analysis of the Cable Television Franchise, 134 U. PA. L. REv. 1335, 1340-45 (1986).

172 See 116 Cong. REc. 23,148 (1970) (statement of Rep. McCulloch).

173 See, e.g., id. at 23,148 (statement of Rep. McCulloch) ("Often where once there were two independent newspaper voices, a newspaper failure or merger has ended competition and tended to produce a stultifying monopoly on news and opinion." (emphasis added)); id. at 23,154 (statement of Rep. Railsback) ("The history of the newspaper industry strikingly reveals the dangerous trend toward a complete elimination of competition between daily newspapers in the same city." (emphasis added)).

174 Michigan Citizens for an Indep. Press v. Thornburgh, 868 F.2d 1285, 1296 (D.C. Cir.), cert. granted, 109 S. Ct. 1952 (1989). 
industry is, however, irrelevant because the NPA provides publishers forming JOAs with monopolistic advantages far exceeding the advantages of a natural monopoly. ${ }^{175}$ Savings from economies of scale and from combined production and distribution are supplemented by profits garnered through activities such as price-fixing, profit-pooling, and market allocation. Such practices are normally prohibited by the antitrust laws but are permitted under the NPA's exemption from such laws. ${ }^{176}$ Furthermore, despite the NPA's avowed goal of preserving multiple autonomous newspapers, JOAs actually "raise[ ] an entry barrier that would not have existed had one of the newspapers gone out of business or if the two newspapers had merged.""177

The NPA also deters would-be publishers by permitting monopolistic advertising practices that create economic obstacles and impede successful market penetration. A common pricing technique permitted under the NPA involves "cartel" rates, in which newspapers operating under a JOA offer an advertiser the opportunity to place an advertisement in both newspapers for a charge that slightly exceeds the cost of advertising in only one newspaper. This practice forces potential competitors to undersell not only the indi-

175 This argument is particularly compelling when, as in the Detroit JOA, the participants are members of newspaper chains. Two newspapers in a given city under common ownership may engage in internal price-fixing and profit-pooling; these practices are, however, even more destructive when backed by the substantial financial resources enjoyed by powerful chains. See Note, supra note 32, at 691-95.

176 See 15 U.S.C. \$ 1802 (1982); see also Comment, The Newspaper Preservation Act: Why it Fails to Preserve Newspapers, 17 Akron L. Rev. 435, 448-49 (1984) (arguing that a JOA fosters newspaper monopolies by encouraging combined production and distribution efforts that result in cost savings and economies of scale for JOA participants which bar other papers from entering the market); Note, supra note 12, at 400-03 (discussing the anti-competitive effects of JOAs, including combined advertising rates that prohibit market entry, and the effects of profit-pooling and market allocation); Note, supra note 32, at 690 (discussing the monopolistic advantages achieved through combined production and distribution operations).

177 Busterna, supra note 83, at 10 . This accusation may be based upon the assumption that a new market entrant faces a more substantial barrier to entry when it seeks to penetrate a market in which there are two newspapers than when it attempts to enter a market dominated by only one newspaper. Newspapers joined in a JOA offer each other no competition, but they are the equivalent of two newspapers operating in one market; as such, they create a barrier to entry that would not have existed had the papers merged into one paper or had one gone out of business. See id.

JOAs also prove more of a deterrent than mergers because merged firms may "dissipat[e] a portion of the assets of the single firm that remain[s] in existence" to finance the merger, whereas in a JOA, "the assets of two or more separate enterprises are pooled together and retained in an existing operation. These assets [thus] are not available for reinvestment in other newspaper ventures." S. REP. No. 535, 91 st Cong., 1st Sess. 10 (1969). 
vidual rates of the two joint-operating newspapers but also the incremental cost of advertising in the second paper participating in the JOA. ${ }^{178}$ Smaller newspapers, which already face substantial disadvantages in an industry heavily dependent upon economies of scale, lose all remaining incentives to enter markets dominated by JOAs. ${ }^{179}$

Accordingly, JOAs stifle the growth of existing smaller newspapers and make continued competition nearly impossible. Despite Congress' recognition that "enactment of [the NPA] would be detrimental to the successful operation of small weekly papers soliciting advertising," 180 the final version of the NPA failed to require or even allow inquiry into the potential impact of a JOA on existing competitors. ${ }^{181}$

In the absence of the NPA, failing newspapers would create market openings that could be filled by "stronger and more viable voice[s]" that would better serve the community. ${ }^{182}$ Instead, the market barriers created by the NPA constrain the industry and frustrate the legislative goal of "furthering editorial independence and diversity." 183 In so conditioning the right to publish on financial means, the NPA abridges critical first amendment rights.

This theory was most recently advanced by the plaintiff in Hearst, which claimed that the proposed JOA between the Seattle newspapers "would impair the first amendment rights of smaller newspapers in the market." 184 In dismissing the first amendment claim as lacking "substantial merit," 185 the Hearst court invoked prior district

178 See Busterna, supra note 83, at 11-12.

179 See, e.g., Note, supra note 32, at 689-90 \& nn.146-47 (Arguing that because of a JOA's ability to combine advertising rates, "[e]ntry barriers, which are already high in the newspaper industry, become nearly insurmountable as a result of a [JOA]. Entry into a joint operating market is even more difficult than entry into a monopoly market."); Note, supra note 12, at 401 ("[F]ar from preserving independent sources of news, the antitrust exemption embodied in the NPA, by permitting combined advertising rates, will serve to eliminate small competing newspapers excluded from these arrangements and bar the entry of new competitors.").

180116 Cong. REc. 23,156 (1970) (statement of Rep. Feighan).

181 See Note, supra note 32 , at 691 .

182 See 116 Cong. Rec. 23,143 (1970) (statement of Rep. Thompson). This argument focuses primarily on the potential market entry of new daily competitors as a means of checking monopolistic control of the press. But of. Glassman, supra note 82, at 11 (arguing that a monopoly does not exist in the newspaper industry because even in cities with only one daily paper, non-daily papers are entering the market and rapidly increasing circulation).

183 Note, supra note 32, at 691.

184 Committee for an Indep. P-I v. Hearst Corp., 704 F.2d 467, 482 (9th Cir.), cert. denied, 464 U.S. 892 (1983).

185 Id. 
court decisions holding that the Act did not abridge first amendment rights. Those decisions, however, were premised on an interpretation of the NPA as "a narrow exception to the antitrust laws for newspapers in danger of failing .... [which] in many respects [is] merely a codification of the judicially created 'failing company' doctrine." 186 The broader, more recent judicial and administrative interpretations of the NPA refute this position by requiring neither a lack of alternate purchasers nor a plunge into a "downward spiral" 187 to exempt a JOA from the antitrust laws. These recent interpretations directly contravene the assumptions of the district court decisions underlying Hearst.

Recent case law, as illustrated by the Michigan Citizens decision, has departed abruptly from precedent. JOAs are no longer granted solely as a last resort to salvage financially troubled newspapers. The Michigan Citizens court ignored both the presence of reasonable alternatives to a $\mathrm{JOA}^{188}$ and the absence of an economic "downward spiral," thereby effectively rejecting the traditional two-prong test. In so doing, it discarded the traditional narrow application of the NPA and negated the reasoning of the earlier courts cited in Hearst, which had relied upon that narrow application in concluding that the NPA did not violate the first amendment. These recent judicial interpretations have "rewritten" the NPA so that first amendment objections to the Act can no longer summarily be rejected by invoking precedent; those decisions are effectively based upon on an essentially different NPA. Threats to first amendment freedoms are far more formidable under an overreaching NPA than under one which is fairly contained.

Claims that the NPA violates the first amendment must also be addressed in light of Supreme Court precedent establishing that the right to publish cannot be conditioned upon financial means. This principle was most clearly articulated in Associated Press $v$. United States, ${ }^{189}$ which held that the Sherman Act was violated by the restrictive by-laws of a news gathering agency. The Associated Press Court rejected the notion that the first amendment provided immunity for publishers from antitrust laws, holding instead that " $[t]$ he First Arnendment affords not the slightest support for the contention that

186 Bay Guardian Co. v. Chronicle Publishing Co., 344 F. Supp. 1155, 1157 (N.D. Cal. 1972); see also City \& County of Honolulu v. Hawaii Newspaper Agency, Inc., 559 F. Supp. 1021, 1030 (D. Haw. 1983).

187 See supra notes $116-21$ and accompanying text.

188 See supra text accompanying note 118.

189326 U.S. 1 (1945). 
a combination to restrain trade in news and views has any constitutional immunity." 190

The Hearst court held Associated Press inapplicable and limited the decision's impact to the facts of that particular case. ${ }^{191}$ In doing so, the court ignored the powerful language in Associated Press mandating that all freedom to publish be uncircumscribed by financial barriers:

Freedom to publish means freedom for all and not for some. Freedom to publish is guaranteed by the Constitution, but freedom to combine to keep others from publishing is not. Freedom of the press from governmental interference under the First Amendment does not sanction repression of that freedom by private interests. ${ }^{192}$

That first amendment rights may in no way be abridged on account of financial status was vehemently reinforced in Buckley $v$. Valeo. ${ }^{193}$ In Buckley, the Court held that the provisions of the Federal Election Campaign Act limiting contributions to candidates for federal elective office violated the first amendment freedom of expression. The Court acknowledged the merits of the statutory goal of equalizing influence on elections but maintained that "the First Amendment's protection against governmental abridgement of free expression cannot properly be made to depend on a person's financial ability to engage in public discussion."194

Associated Press and Buckley establish that the right to publish may not be circumscribed by financial constraints. The economic power that accrues to members of a JOA impermissibly treads upon the first amendment rights of smaller competitors and would-be market entrants. In holding that no first amendment violation existed, the Hearst court presumed that the NPA's antitrust exemption did not affect "the content of speech" of smaller newspapers. ${ }^{195}$ The lack of alternative voices in a JOA-dominated market, however, effectively intrudes upon the content of speech both by discouraging the expression of existing papers and by preventing newspapers from entering the market. The NPA's unrestrained scope unduly infringes

190 Id. at 20.

191 See Committee for an Indep. P-I v. Hearst Corp., 704 F.2d 467, 483 (9th Cir.) (" $[\mathrm{T}]$ he [Associated Press] Court held only that the first amendment does not insulate news-gathering organizations from the antitrust laws."), cert. denied, 464 U.S. 892 (1983).

192 Associated Press, 326 U.S. at 20.

193424 U.S. 1 (1976).

194 Id. at 49.

195 Hearsi, 704 F.2d at 483. 
on both the would-be publisher's right to publish and the public's right to information disseminated by "diverse and antagonistic sources." 196

\section{Conclusion}

The Supreme Court's decision to review the recent JOA controversy in Detroit reaffirms the need for judicial and legislative reexamination of the NPA in light of its failure to achieve its avowed purposes. ${ }^{197}$ The NPA has neither increased editorial quality and diversity nor halted the decline of two-newspaper cities. Instead, it has inhibited first amendment rights by erecting additional economic barriers to entry in a newspaper industry already dominated by large corporate chains. The NPA has further augmented these chains' power because its vague language has been subject to judicial and administrative manipulation, which has generated unnecessary JOAs such as the one recently disputed in Detroit. The blanket approval given to JOAs ignores the government's lack of Constitutional power to enforce the NPA and creates the potential for further first amendment infringement.

196 Associated Press, 326 U.S. at 20.

197 Less drastic measures than an outright repeal of the NPA have been suggested. See, e.g., NPA Oversight Hearing, supra note 42 (statement of Robert Picard, at 4-5) (setting forth 10 suggestions for amending the Act, including the elimination of price fixing and profit pooling); Lacy, supra note 132, at 160 (suggesting that "[r]euniting the advertising and business departments with the editorial departments, while keeping production and distribution separate, might work to further make JOA newspapers similar to competitive newspapers"). 

" 


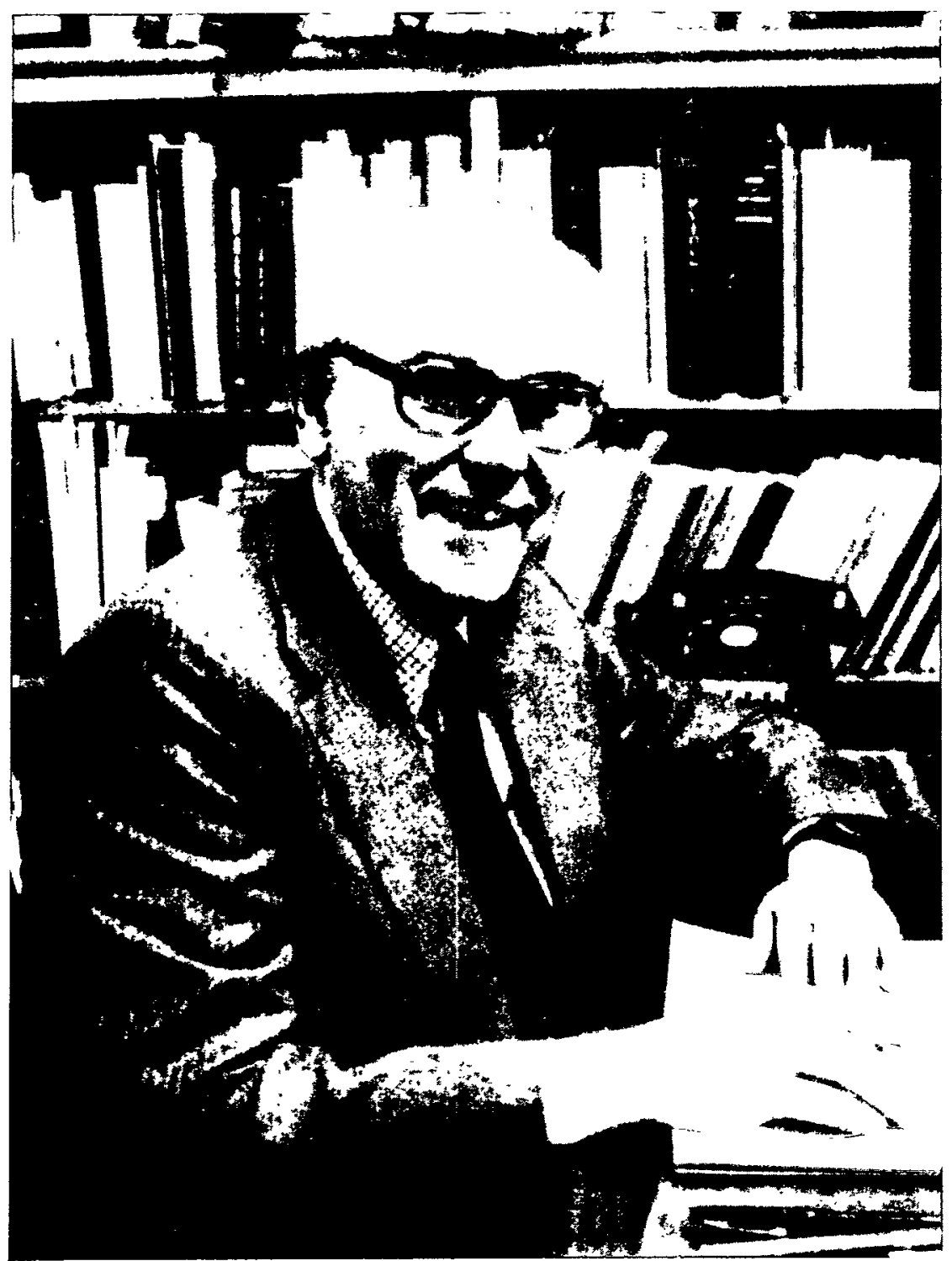

A. Leo Levin

The editors of the University of Pennsylvania Law Review take great pleasure in dedicating this issue to A. Leo Levin, the Leon Meltzer Professor of Law Emeritus. The remarks of the distinguished group of contributors who have joined in this tribute to Professor Levin illustrate his rich and varied accomplishments both as a scholar and teacher at the Law School and in his significant roles in the public service. Professor Levin's engaging and vibrant personality and inimitable wit have left its mark on a generation of law school graduates. The Law Review wishes him well in his future endeavors. 